\title{
WestVirginiaUniversity
}

THE RESEARCH REPOSITORY @ WVU

West Virginia Agricultural and Forestry Experiment

Davis College of Agriculture, Natural Resources

Station Bulletins

And Design

$1-1-1959$

\section{West Virginia farming : a pictorial comparison among counties}

G. E. Toben

L. T. Warman

Follow this and additional works at: https://researchrepository.wvu.edu/ wv_agricultural_and_forestry_experiment_station_bulletins

\section{Digital Commons Citation}

Toben, G. E. and Warman, L. T., "West Virginia farming : a pictorial comparison among counties" (1959). West Virginia Agricultural and Forestry Experiment Station Bulletins. 433.

https://researchrepository.wvu.edu/wv_agricultural_and_forestry_experiment_station_bulletins/411 @ WVU. It has been accepted for inclusion in West Virginia Agricultural and Forestry Experiment Station Bulletins by an authorized administrator of

The Research Repository @WVU. For more information, please contact ian.harmon@mail.wvu.edu. 
6. W.

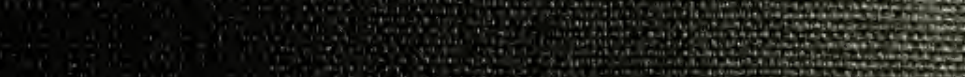

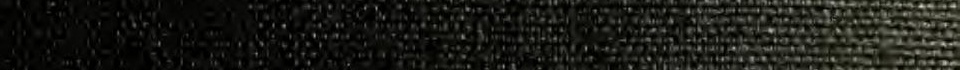

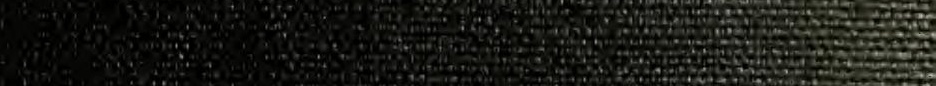
15 , (1)

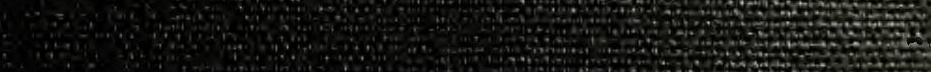

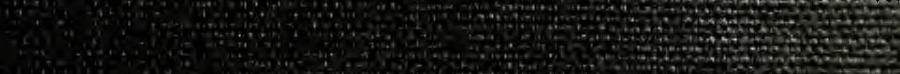

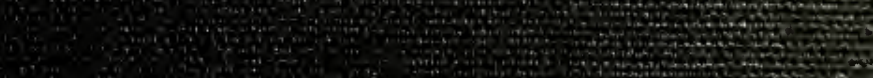

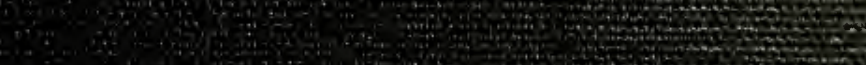

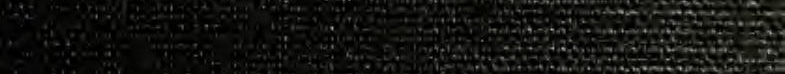

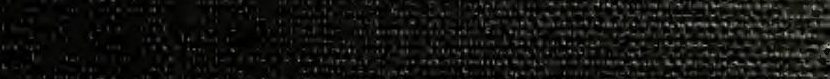
$\because \quad \therefore \quad \therefore$ and

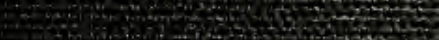
वैin (1)

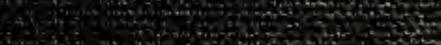

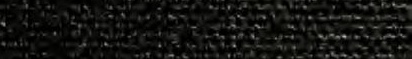

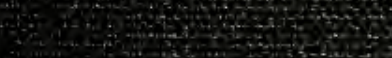
20.5 क

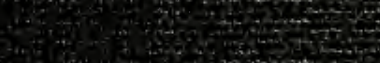
(2)

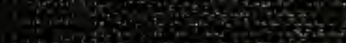

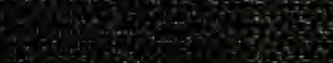

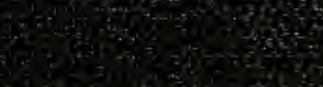
(n)

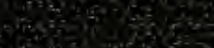
$\cos ^{2} x=2$ 
Digitized by the Internet Archive in 2010 with funding from

Lyrasis Members and Sloan Foundation 


\section{West Virginia Farming-}

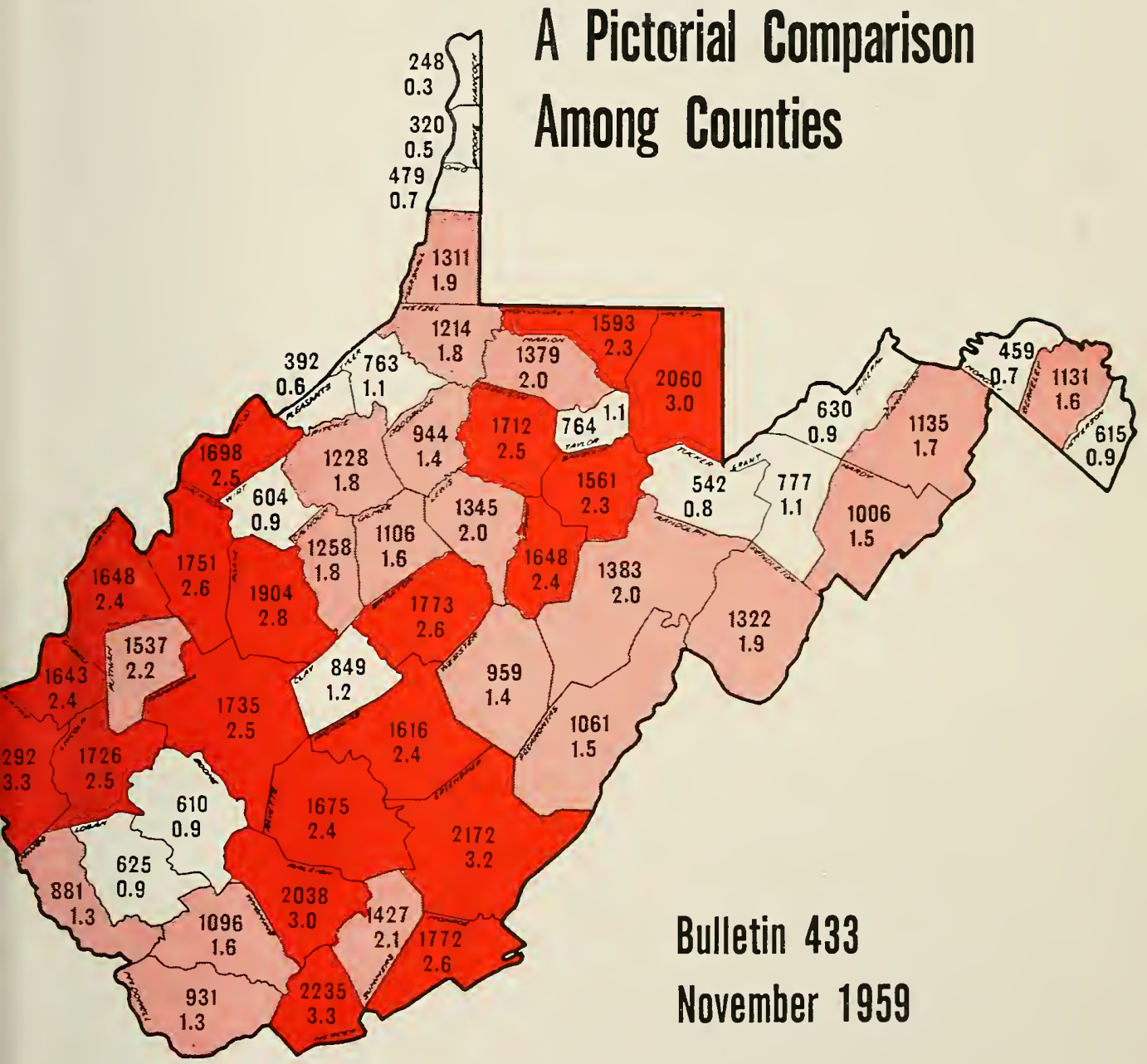

\section{WEST VIRGINIA UNIVERSITY AGRICULTURAL EXPERIMENT STATION}




\title{
THE AUTHORS
}

Authors of West Virginia Farming-A Pictorial Comparison Among Connlies are G. E. Toben and L. T. Warman. G. E. Toben is Associate Professor of Agricultural Economics in the Department of Agricultural Economics and Rural Sociology and Associate Agricultural Economist in Farm Management in the Agricultural Experiment Station. L. T. Warman, formerly a graduate student in the Department of Agricultural Economics and Rural Sociology, is now assistant county agent in Harford County, Maryland.

\section{ON THE COVER}

This two-color map is one of 23 that clearly illustrates differences among farms in West Virginia. Factors given in the maps in this Bulletin include farm incomes, land use, livestock, farm operators, and level-of-living. The maps offer a pictorial description of individual counties in relation to neighboring counties.

\author{
West Virginia UNTIERSITY \\ Agricultural Experinient Station \\ College of Agriculture, Forestri, and Home Economics \\ A. H. VanLandinghani, Director \\ MORGANTOWN
}




\section{West Virginia Farming-}

A Pictorial Comparison Among Counties

by

G. E. Toben

L. T. Warman

WEST VIRGINIA UNIVERSITY AGRICULTURAL EXPERIMENT STATION 



\section{Contents}

SUMMARY

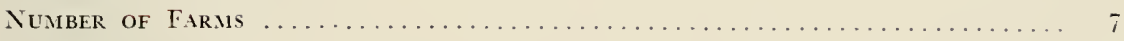

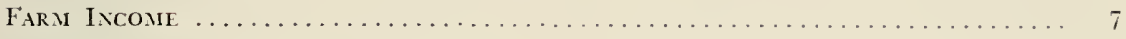

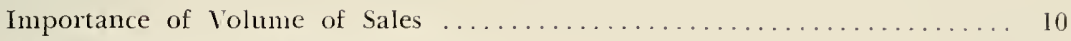

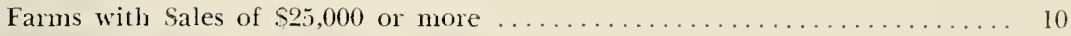

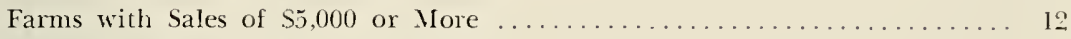

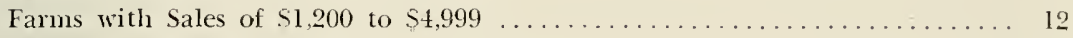

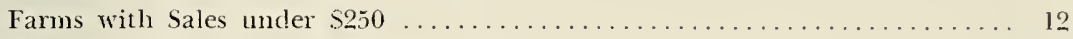

Farm Income after Paying Some Expenses . . . . . . . . . . . . . . . 16

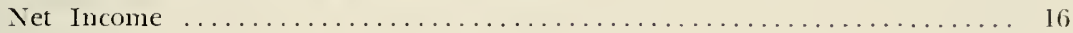

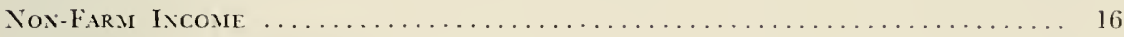

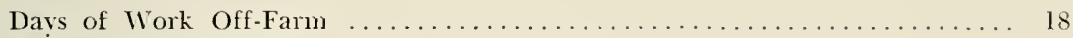

Farmers Working 100 Dars or More Off-Farm ................. 20

Changes in Imount of Off-Farm Work .................. 20

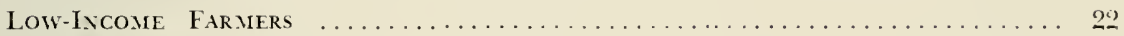

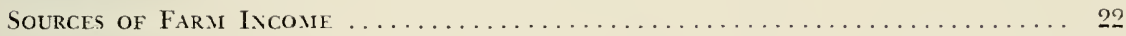

Livestock Income $\ldots \ldots \ldots \ldots \ldots \ldots \ldots \ldots \ldots \ldots \ldots \ldots \ldots \ldots \ldots \ldots \ldots$

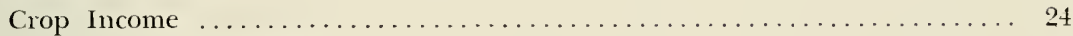

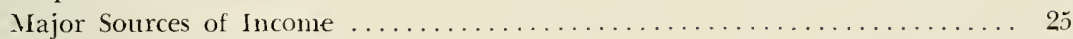

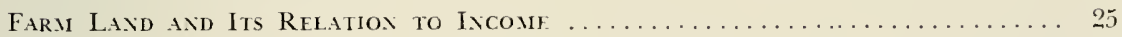

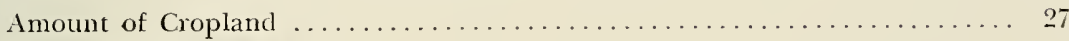

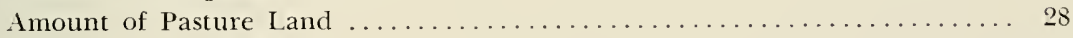

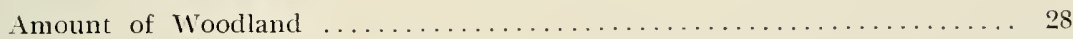

Livestock SALES AND Their Rflatiox to Ixcome ................. 31

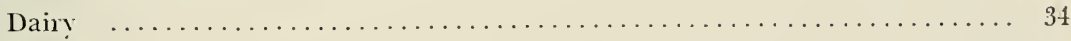

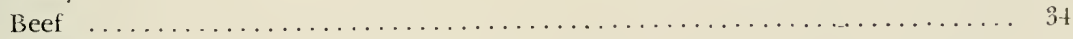

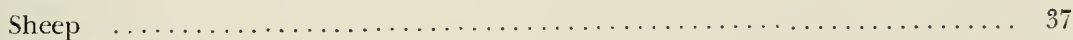

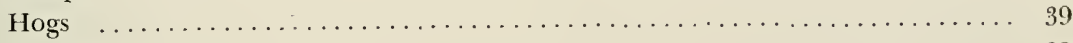

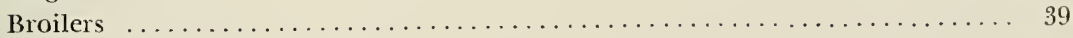

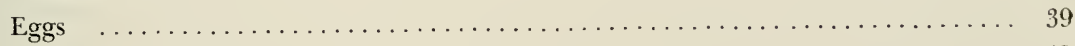

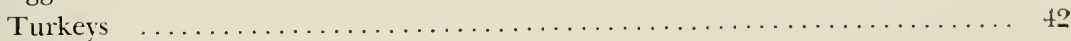

Relation of PuRchased FeEd to Lliestock SAl.es $\ldots \ldots \ldots \ldots \ldots \ldots \ldots \ldots \ldots \ldots$

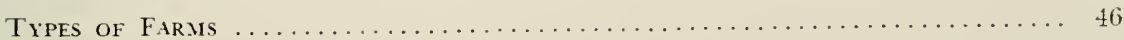

Ranking Agriculturil Counties $\ldots \ldots \ldots \ldots \ldots \ldots \ldots \ldots \ldots \ldots \ldots \ldots \ldots \ldots$

LEVEL-OF-LIVING $\ldots \ldots \ldots \ldots \ldots \ldots \ldots \ldots \ldots \ldots \ldots \ldots \ldots \ldots \ldots \ldots \ldots$ 


\section{Summary}

W

EST Virginia farmers had a lower average net farm income in 1954 than farmers in any other state. Less than 1 per cent of West Virginia farmers had farm sales of $\$ 25,000$ or more and about 90 per cent had farm sales of less than $\$ 2,500$. This lorv-income situation is a problem not only to agriculture, but also of concern to industry, government, and education. Planning is necessary to improve the situation.

The principal sources of cash receipts from farms ranked according to their relative importance were dairy products, broilers, beef cattle, and eggs. Each of the other sources contributed less than 10 per cent of casl farm income. Those contributing 4 to 10 per cent of the cash receipts were apples, turkeys, and dairy animals.

Acreages in farms and land use influenced the farm income. Farms with gross sales under $\$ 1,200$ averaged less than 100 acres. Those with sales of $\$ 5,000$ or more averaged more than 300 acres. Farms with low incomes had a higher proportion of woodland; those with high incomes had a higher proportion of cropland.

A majority of the farms with relatively large gross sales are in the eastern part of the State, particularly in the Eastern Panhandle. The majority of the low-income farms are in the central and southern parts.

Many farmers worked away from their farms. About one-third had 200 days or more of off-farm work. Among economic groups, income. from work off-farm increased in amount as the farm sales declined.

The farm-operator level-of-living was generally low. Farmers in nearly 50 per cent of the counties in West Virginia had indexes of levelof-living that were among the low one-fifth of the counties in the nation. In only 11 per cent of the counties were indexes greater than the United States average. 


\section{West Virginia Farming A Pictorial Comparison Among Counties}

G. E. TOBEN and L. T. WARMAN

IFFERENCES among farms in West Virginia are many and varied. Understanding these differences, as well as knowing the similarities will help in preparing agricultural plans. This publication shows some of the relationships which influence the economic position of farmers in West Virginia. Particular emphasis is placed on factors which can be compared on county bases. These factors include items related to farm incomes, land use, livestock, farm operators, and level-of-living. To a large extent the factors are shown by counties on State maps. This procedure provides a pictorial description of individual counties in relation to neighboring counties. Legends on maps show areas of location and levels of concentration. Generally, the legend shows one level of concentration that accounts for about half the farms.

The 1954 Census of Agriculture is the principal source of information for this publication. ${ }^{1}$ Most presentations are based on an analysis of census data. Only to a small extent are direct tabulations from the census repeated in this bulletin. Original data from which interpretations are made can be located readily because the sources are shown for each table and map.

\section{Number of Farms}

The 1954 Census of Agriculture reported 68,570 farms in West Virginia. This was nearly 1.5 per cent of all farms in the United States.

Wayne County had the largest number of farms; Hancock the smallest number (Map 1). Only five counties had more than 2,000 farms: these were Wayne, Mercer, Greenbrier, Preston, and Raleigh. The fire counties with less than 500 farms were Hancock, Brooke, Pleasants, Morgan, and Ohio.

\section{Farm Income}

Farmers in West Virginia, compared with those in other states, had a relatively low level of farm sales in 1954. Less than 1 per cent of the

${ }^{1}$ U. S. Bureau of Census, U. S. Census of Agriculture, 1954, Vol. I, Pt. 15 and Vol. I1. 
Table 1. Number and Proportion of Farms by Economic Classfes In i'est Virginia with United States Comparisons, 1954*

\begin{tabular}{|c|c|c|c|c|}
\hline \multirow{2}{*}{$\begin{array}{l}\text { ECONOMIC } \\
\text { CLASS }\end{array}$} & \multirow{2}{*}{$\begin{array}{c}\text { VALUE OF FARM } \\
\text { PRODUCTS SOLD } \\
\text { PER FARM }\end{array}$} & \multirow{2}{*}{$\begin{array}{c}\text { NUMBER OF } \\
\text { FARMS IN } \\
\text { WEST VIRGINIA }\end{array}$} & \multicolumn{2}{|c|}{ PER CENT by ECoxomic Class } \\
\hline & & & W. VA. & U. S. \\
\hline 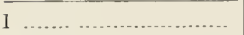 & $\$ 25,000$ or more & 355 & 0.5 & 2.8 \\
\hline II & $\$ 20,000$ to $\$ 24,999$ & 1,148 & 1.7 & 9.4 \\
\hline III & 5,000 to $\quad 9,999$ & 2,269 & 3.3 & 14.8 \\
\hline IV & 2,500 to $, 4,999$ & 3.162 & 4.6 & 17.0 \\
\hline V & 1,200 to 2,499 & 5,737 & 8.4 & 15.9 \\
\hline $\mathrm{VI} * *$ & 250 to 1,199 & 8,833 & 12.9 & 9.7 \\
\hline All commercial & & $\overline{21.504}$ & 31.4 & $69 . \overline{6}$ \\
\hline Part-time** .... & 250 to & 12,039 & 17.6 & 12.0 \\
\hline Residential ............... & Less than 250 & 35,003 & 51.0 & 18.3 \\
\hline Abuormal & & & & \\
\hline (Institutional) ... & & 24 & .0 & 0.1 \\
\hline & & $\overline{68.570}$ & $\overline{100.0}$ & $\overline{100.0}$ \\
\hline
\end{tabular}

$*$ U. S. Bureau of Census, U. S. Census of Agriculture, 1954, Vol. 11, pp. 1162 and 1165.

* Farms with sales of $\$ 250$ to $\$ 1,199$ were Class V1, provided the operator had less than 100 days of off-farm work and income of the operator and members of his family from non-farm sources was less than the value of all farm products sold; the other farms in this income group were classified as part-time.

farms had sales of $\$ 25,000$ or more (Table 1). About 2 per cent had sales of $\$ 10,000$ or more. Less than 6 per cent had sales of $\$ 5,000$ or more.

When West Virginia was compared with the other states it was found that only North Carolina, Kentucky, and Tennessee had a smaller proportion of farms with sales of $\$ 25,000$ or more. Both Mississippi and W'est Virginia had 2.2 per cent of their farms with sales of $\$ 10,000$ or more and only Tennessee had a smaller proportion. West Virginia had the smallest proportion of farms with sales of $\$ 5,000$ to $\$ 10,000$, and the smallest proportion of all farms with sales of $\$ 5,000$ and more. It also had the smallest proportion of farms with sales of $\$ 2,500$ or more.

More than 80 per cent of the farms in West Virginia sold less than $\$ 1,200$ of farm products. No other state had so large a proportion of low-income farms.

The Census classified farms with sales of less than $\$ 1,200$ into three groups. One group, called commercial class VI farms, was comprised of farms with sales of $\$ 250$ to $\$ 1,199.2$ Seven states, Mississippi, Alabama, Tennessee, Kentucky, South Carolina, Arkansas, and Georgia, had more low-income farms in this group than West Virginia. A second group was called part-time farms. By a slight margin, West Virginia had the largest proportion of part-time farms. Both the commercial class VI larms and the part-time farms had farm sales of $\$ 250$ to $\$ 1,199$; the principal difference between the two was in the amount of work off the farm. Only four states, Alabama, Tennessee, Mississippi, and South Carclina, had a larger proportion of farms in these two groups. The

s-See footnote to Table 1. 


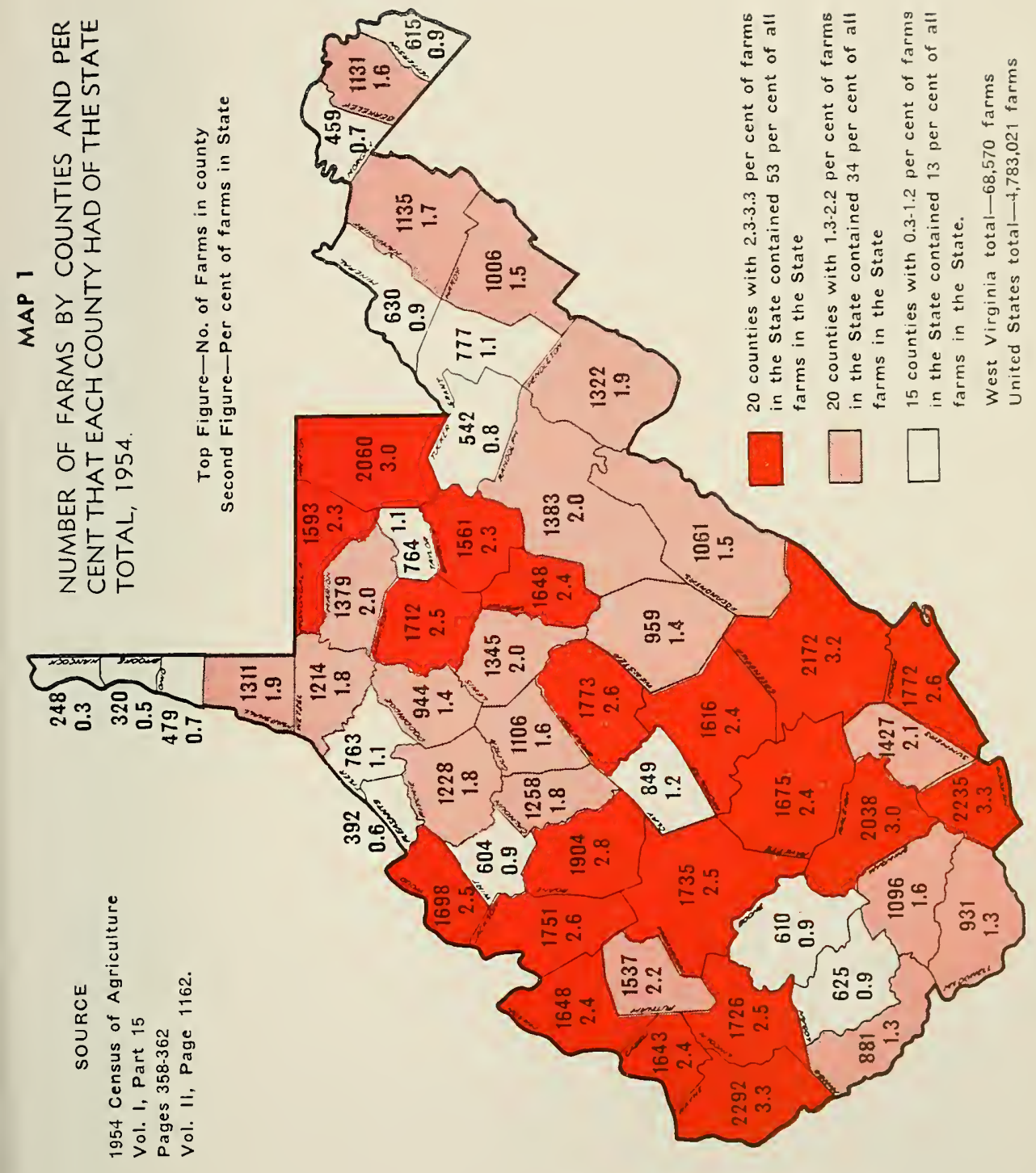


third group of low-income farms was called residential farms. Each of these farms sold less than $\$ 250$ of farm products. In West Virginia more than half the farms were in this group. No other state had more than one-third of its farms selling less than $\$ 250$ of farm products.

\section{IMPORTANCE OF VOLUME OF SALES}

In West Virginia, farms with largest volume of sales were relatively few in numbers but extremely important in gross volume of sales. Those with sales of $\$ 25,000$ or more represented less than 1 per cent of the farms, but accounted for more than 20 per cent of all farm sales in the State (Table 2). About 6 per cent of all farms in the State had sales of $\$ 5,000$ or more, yet these accounted for nearly 60 per cent of all sales. By contrast, more than 50 per cent of all farms sold less than $\$ 250$ of farm products and were responsible for only 3 per cent of the total farm sales in the State.

Farms with sales of $\$ 25,000$ or more were particularly important in crop sales. Even though they accounted for less than 1 per cent of all farms they had nearly half of all crop sales in the State. The amount of income from livestock sales from these farms was relatively less important than from crops. They accounted for 14 per cent of all sales of livestock and livestock products. Farms which had sales of $\$ 5,000$ or more accounted for 6 per cent of all farms and had 65 per cent of all crop sales and 57 per cent of all livestock sales.

\section{FARMS WITH SALES OF $\$ 25,000$ OR MORE}

Less than 1 per cent of the farms in the State in 1954 had sales of $\$ 25,000$ or more. More than 50 per cent of these farms were in five counties in the Eastern Panhandle (Map 2). In each of these counties, more than 8 per cent of the farms were in this income group.

Table 2. Relative Importance of Sales of Farm Products, by Economic: Class of Farms, West Virginia, 1954*

\begin{tabular}{|c|c|c|c|c|c|}
\hline \multirow{2}{*}{$\begin{array}{l}\text { ECONOMIC } \\
\text { Class }\end{array}$} & \multirow{2}{*}{$\begin{array}{c}\text { VALUE OF FARM } \\
\text { PRODUCTS SOLD } \\
\text { PER FARM }\end{array}$} & \multirow{2}{*}{$\begin{array}{c}\text { NUMBER } \\
\text { OF } \\
\text { FARMS }\end{array}$} & \multicolumn{3}{|c|}{ Per Cent of Sales by Economic Classes } \\
\hline & & & $\begin{array}{l}\text { Alu } \\
\text { SALES }\end{array}$ & $\begin{array}{c}\text { AlL } \\
\text { Crops }\end{array}$ & $\begin{array}{c}\text { ALL } \\
\text { LIVESTOCK }\end{array}$ \\
\hline I & $\$ 25,000$ or more & 355 & 22 & 47 & 14 \\
\hline $11 \ldots . .$. & 10,000 to 24,999 & 1,148 & 19 & 10 & 22 \\
\hline III ... & 5,000 to 9,999 & 2,269 & 18 & 8 & 21 \\
\hline $1 \mathrm{~V}$ & 2,500 to 4,999 & 3,162 & 13 & 7 & 14 \\
\hline V $\ldots . .$. & 1,200 to 2,499 & 5,737 & 11 & 9 & 12 \\
\hline$V I * *$ & 250 to 1,199 & 8,833 & 6 & 6 & 6 \\
\hline Part-Time** & 250 to 1,199 & 12,039 & 7 & 8 & 7 \\
\hline Residential ......... & Less than 250 & 35,003 & 3 & 3 & 3 \\
\hline $\begin{array}{l}\text { Abnormal } \\
\text { (Institutional) }\end{array}$ & & 24 & 1 & 2 & 1 \\
\hline
\end{tabular}

*U. S. Bureau of Census, U. S. Census of Agriculture, 1954, Vol. II, pp. 1222-1223, and 1165 .

* See footnote to Table 1. 


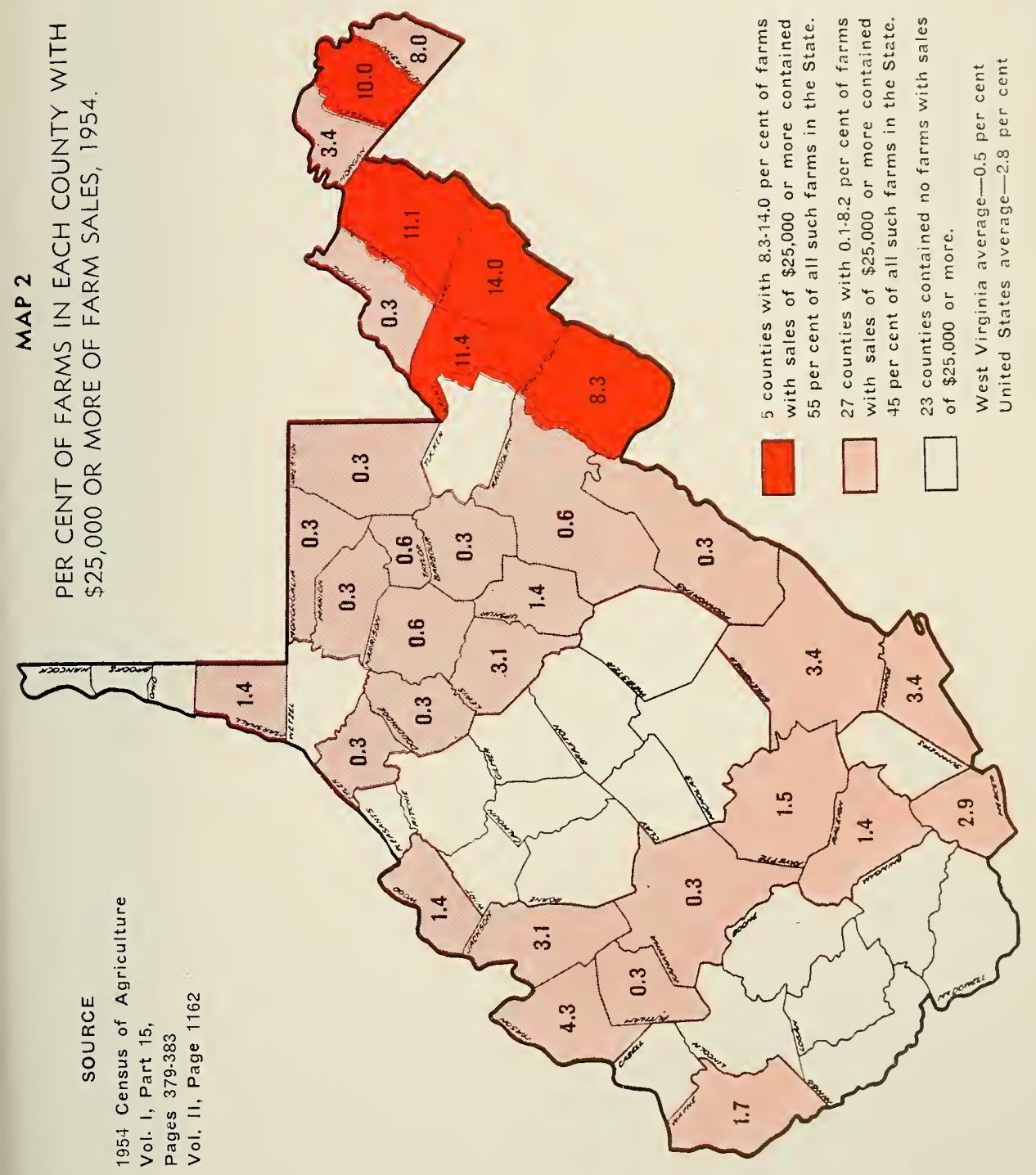


Eight counties, each of which had from 2 to 8 per cent of the farms in the county with sales of $\$ 25,000$ or more, included 32 per cent of all such farms in the State. Each of the 13 counties having 2 per cent or more of the farms in the county with sales of $\$ 25,000$ or more had 10 or more of these farms. These counties, representing 24 per cent of the total, contained 86 per cent of all such farms. Another 34 per cent of the counties contained the balance. There were 42 per cent of the counties with no farms having sales of $\$ 25,000$ or more in 1954 .

\section{FARMS WITH SALES OF $\$ 5,000$ OR MORE}

About 6 per cent of all farms in the State had sales of $\$ 5,000$ or more in 1954. The largest proportion of these farms was in Jefferson County, where 45 per cent had sales of $\$ 5,000$ or more (Map 3). In the State, nine counties, or 16 per cent of the total, accounted for 54 per cent of these farms. Seven of these counties are in the Eastern Panhandle and two are on the western border.

Nineteen counties had from 3 to 10 per cent of the farms with sales of $\$ 5,000$ or more. These represent a third of the counties in the State and 35 per cent of the farms in this income group. Another 40 per cent of the counties had only 11 per cent of the farms within this volume of sales. Nine per cent of the counties had no farms with sales as large as $\$ 5,000$; these counties are all in the southern part of the State.

\section{FARMS WITH SALES OF \$1,200 TO \$4,999}

Thirteen per cent of all farms sold from $\$ 1,200$ to $\$ 4,999$ of farm products. The heaviest concentration of these was in the northern part of the State (Map 4). There were 20 counties that had from 18 to 37 per cent of all farms in each county in this income group. These counties accounted for 50 per cent of all farms selling from $\$ 1,200$ to $\$ 4,999$ of farm products.

Fourteen counties in the southern and south central portion of the State each had less than 8 per cent of their farms with sales of $\$ 1,200$ to $\$ 4,999$. None of these counties had more than 3 per cent of their farms with sales of $\$ 5,000$ or more. In all 14 counties more than 90 per cent of the farms had sales of less than $\$ 1,200$.

\section{FARMS WITH SALES UNDER $\$ 250$}

More than 50 per cent of West Virginia's farms sold less than $\$ 250$ of farm products in 1954. Individually and collectively they contributed little to the total of agricultural products sold in the State.

All counties had some farms with sales of less than $\$ 250$ (Map 5). Twenty had 52 per cent of all such farms. Most of these were in the southern and central part of the State; some were in the northern part. 


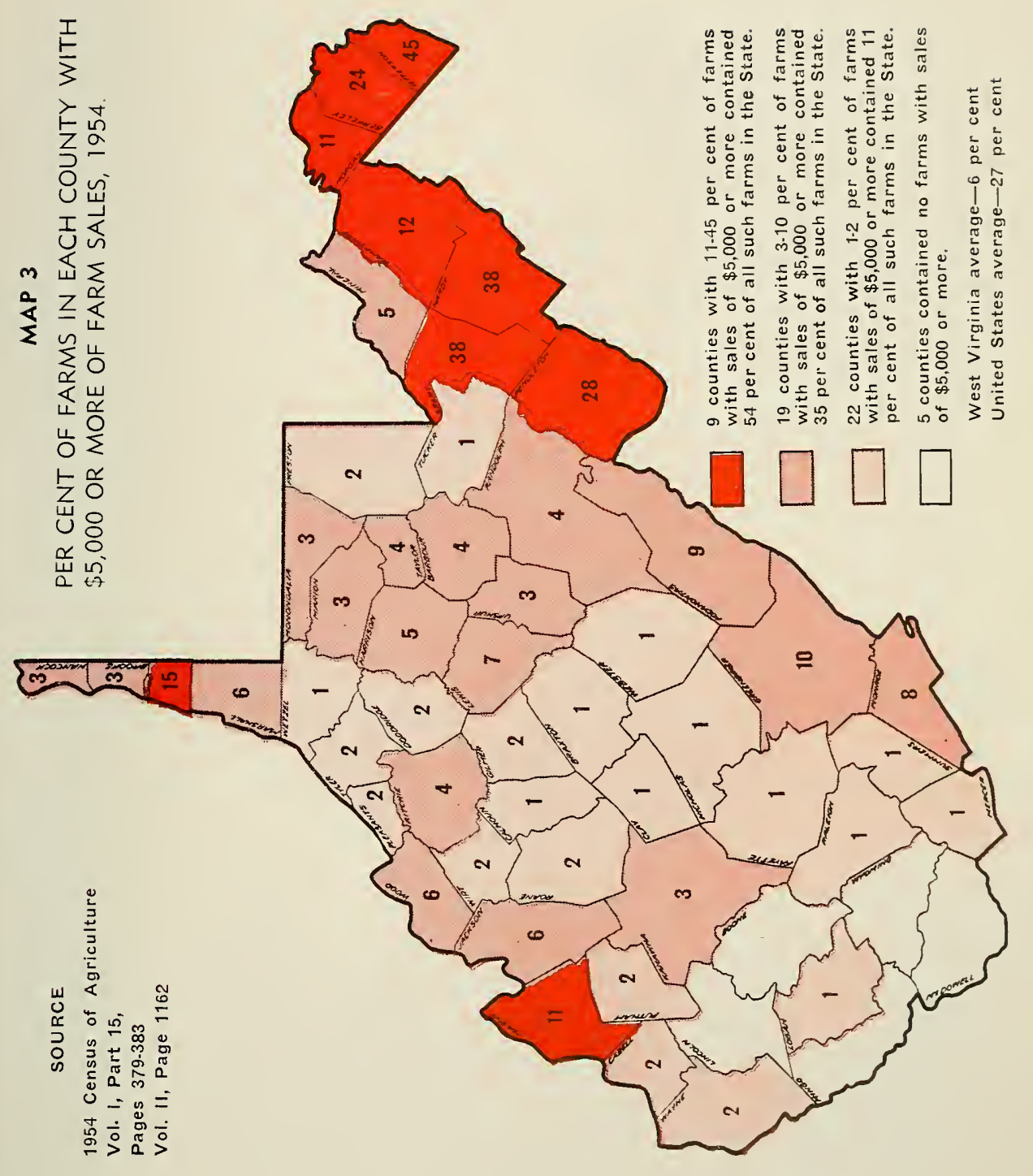




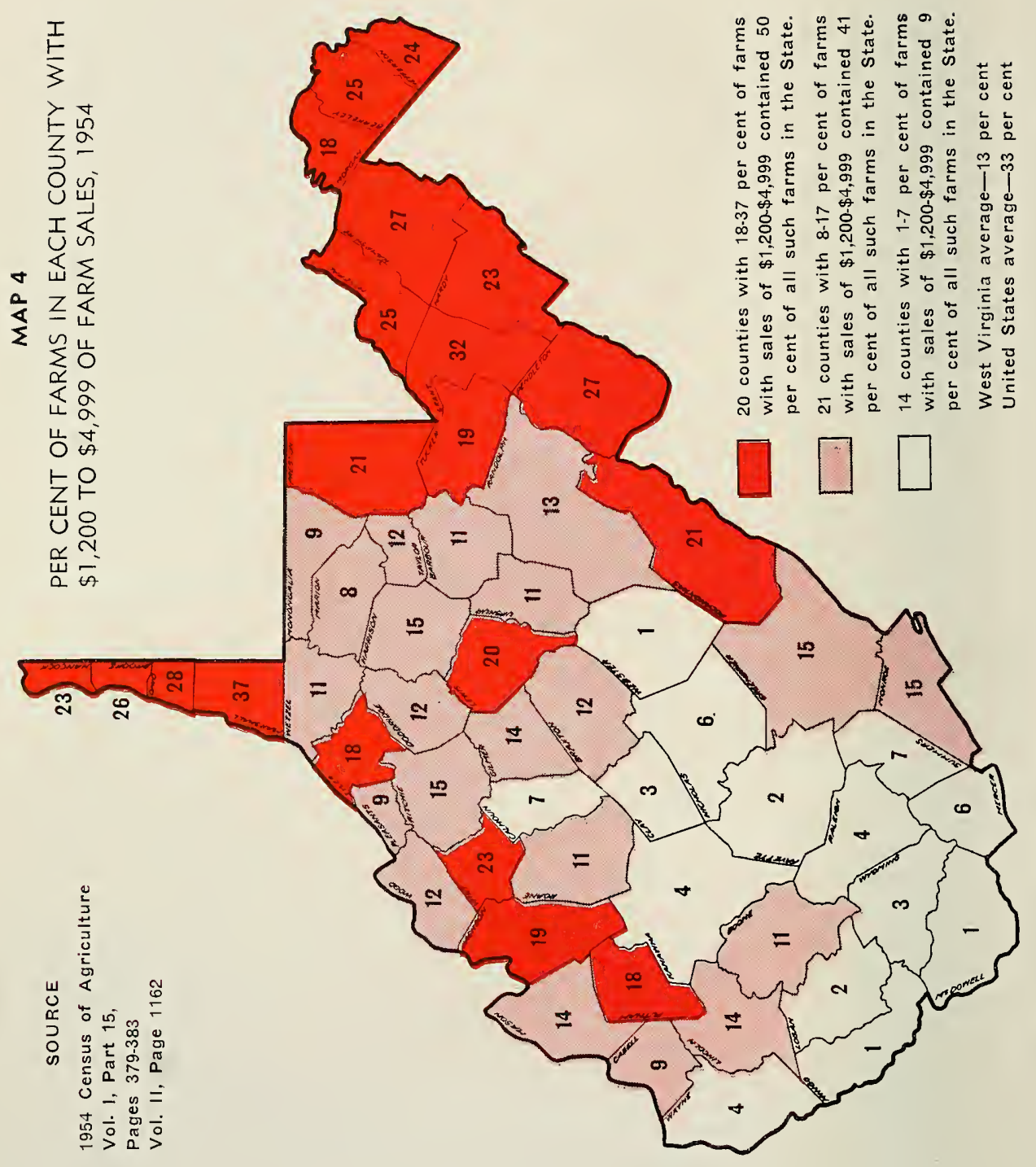


Most counties with the smallest proportion of farms with low volume of sales were in the eastern and western parts of the State.

\section{FARM INCOME AFTER PAYING SOME EXPENSES}

The Census of Agriculture provides information on selected items of farm expenditures; these items are machine hire, hired labor, purchased feed, gasoline, fertilizer and lime. Even though these are not all the items of farm expenses, they account for many of the important ones. When the costs of these items are declucted from the value of farm sales, a measure of return called "adjusted farm income" is provided."

The adjusted farm income varies considerably among counties (Map 6). Eight counties produced more than 50 per cent of West Virginia's adjusted farm income. Seven of these are located along the eastern border of the State, and the other is on the western border.

Twenty-nine per cent of the counties produced an additional 29 per cent of the adjusted farm income. Most of these counties are located in the northern half of the State. 'The remaining 20 per cent of the adjusted farm income came from 49 per cent of the counties.

Four counties, located in the southern part of the State, had selected expenditures which were greater than the total value of all farm products sold. In each of these counties less than 2 per cent of the farms were commercial farms selling $\$ 5,000$ or more of farm products. More than 80 per cent of the farms produced less than $\$ 250$ of farm products. Probably a large proportion of the farm expenses were incurred in production of goods for home consumption rather than for sale.

\section{NET INCOME}

The average realized gross income per farm was the lowest of any state in the Union. The realized gross income includes the cash receipt from farm marketings, government payments, the value of products for home consumption, and the rental value of farm dwellings. Deducting farm production expenses from realized gross income and adjusting for changes in farm inventories gives net income per farm. The average net income per farm in West Virginia was lower than in any other state.

\section{Non-Farm Income}

More than 50 per cent of the farm families in West Virginia had off-farm income which exceeded the value of agricultural products sold. No other state had this high a proportion."

${ }^{3}$ U. S. Bureau of Census, U. S. Census of Agriculture, 1954, Vol. I, pt. 15, pp. 376-37S, line 3 minus pp. 384-388 lines $31,35,45,49,52$ and 57 .

"The Farm Income Situation USDA, AMS, FIS-170, Sept. 195s, pp. 13 and 17.

"T. S. Bureau of Census, U. S. Census of Agriculture, 1954, Vol. I1, pp. 1168-1173. 


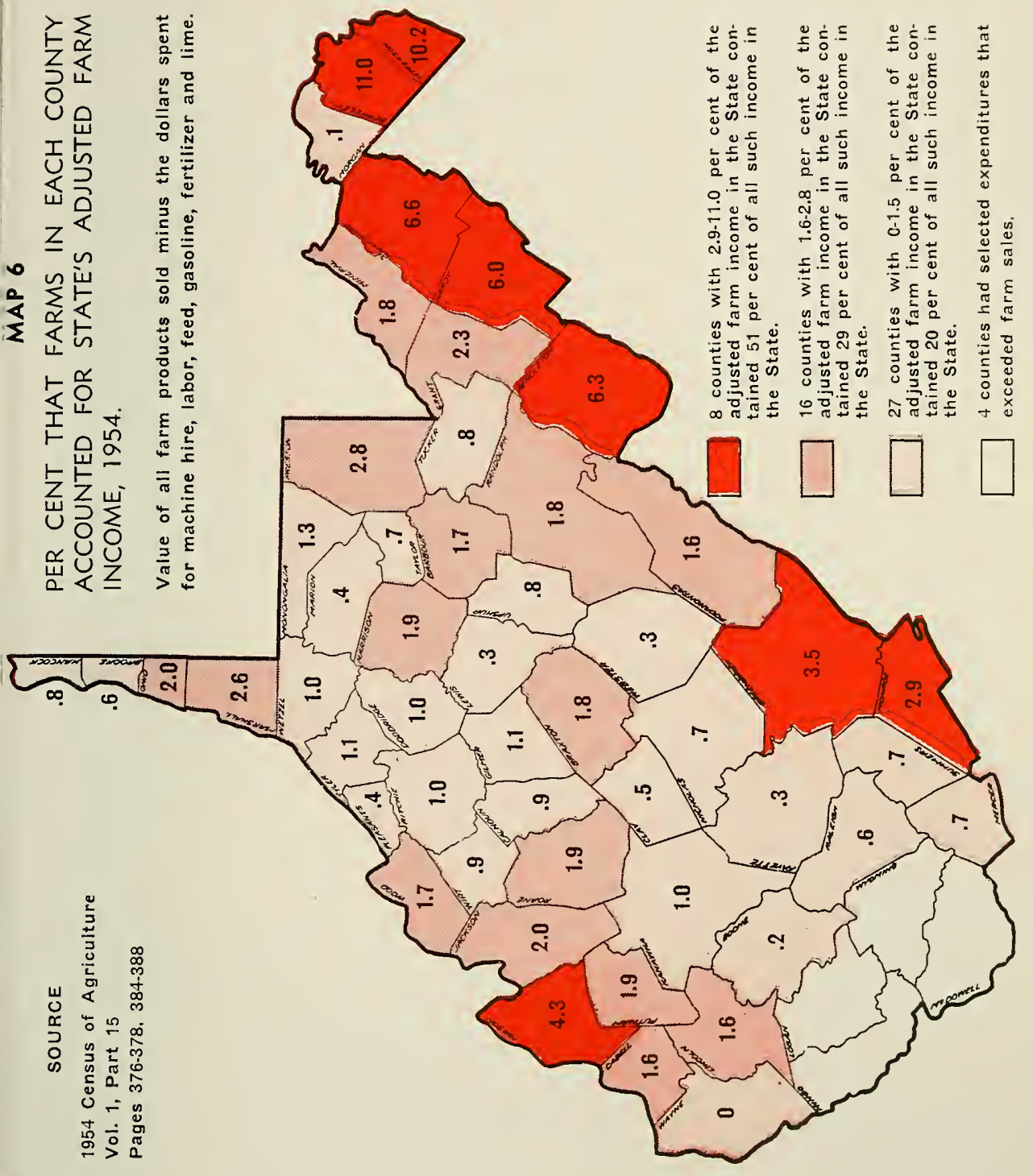


The proportion of farms with non-farm income exceeding the value of agricultural sales varied among counties (Map 7). Two or more counties may have similar proportions, but due to different causes. For example, one county with a low proportion of farms with non-farm income exceeding farm sales may have a high proportion of farms with large incomes. Another county may also have a small portion because of poor opportunities for off-farm employment.

Twenty counties hạd nearly half of the farms on which income from non-farm sources exceeded farm sales. These were distributed from the most northern to the most southern county. McDowell, with 81 per cent of such farms, had the largest proportion; and Grant County, with 25 per cent, had the smallest proportion.

\section{DAYS OF WORK OFF-FARM}

More than 50 per cent of the farms in West Virginia reported some off-farm work for income (Table 3). Only five states had a higher proportion-Utah, New Hampshire, Washington, Maine, and Oregon. In West Virginia, an average of 43 per cent of all farmers worked off-farm for 100 days or more. Only New Hampshire, Washington, and Utah had slightly higher proportions. West Virginia exceeded the United States in the proportion of farmers working off the farm on all farms selling $\$ 1,200$ or more farm products.

Off-farm employment was not limited to low-income farms. Some operators in all economic classes of farms engaged in off-farm work. However, the amount of farm sales declined as the proportion of farmers working off farms increased. Almost 30 per cent of West Virginia farmers selling $\$ 25,000$ or more of farm products had some off-farm employment;

\section{Table 3. Proportion of Farmers ITorking off-Faril by Economic Class of Faris, West Virginia with United States}

Comparisons, 1954*

\begin{tabular}{|c|c|c|c|c|c|}
\hline \multirow[t]{2}{*}{$\begin{array}{l}\text { ECONOMIC } \\
\text { Class }\end{array}$} & \multirow[t]{2}{*}{$\begin{array}{c}\text { VALte OF } \\
\text { FARM SALES }\end{array}$} & \multicolumn{2}{|c|}{$\begin{array}{l}\text { PER CENT OPERATORS } \\
\text { WORKING OFF-FARM }\end{array}$} & \multicolumn{2}{|c|}{$\begin{array}{l}\text { PER CENT OPERATORS } \\
\text { WORKING OFF-FARM } \\
100 \text { DAYS OR MORE }\end{array}$} \\
\hline & & W. VA. & U. S. & W. V. & U. S. \\
\hline 1 & $\$ 25,000$ or orer & 29 & 20 & 16 & 8 \\
\hline 11 & 10,000 to 24,999 & 35 & $2 \pi$ & 13 & $\tau$ \\
\hline $1 I I$ & 5,000 to 9,999 & 41 & 31 & 20 & 10 \\
\hline $1 \mathrm{~V}$ & 2,500 to 4.899 & 47 & 36 & 25 & 16 \\
\hline $\mathrm{r}$ & 1,200 to 2,499 & 48 & 44 & 31 & 24 \\
\hline V1 \& Part-time. & 250 to 1,199 & 55 & 56 & 39 & 39 \\
\hline Rural Resident & Under 250 & 63 & 65 & 52 & 56 \\
\hline All Farms & & 57 & 45 & 43 & 28 \\
\hline
\end{tabular}

*U. S. Bureau of Cencus, U. S. Census of Agriculture, 1954, Vol. 1, Pt. 15, pp. 43S-439, and Vol. I1, pp. 1168 to 1171. 


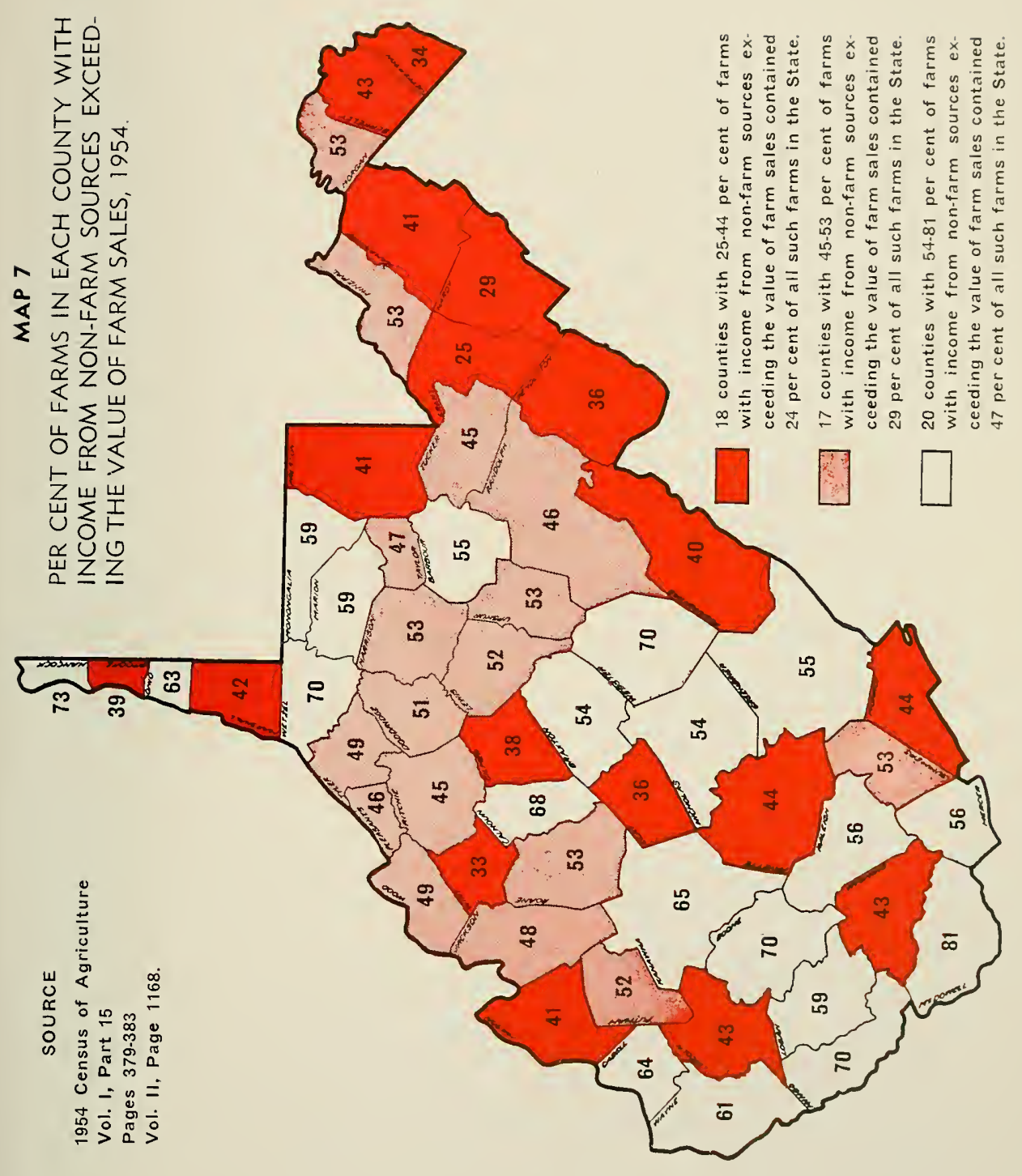


16 per cent worked 100 days or more off the farm. These proportions increased with decreased farm income. More than half of all farmers in IVest Virginia sold less than $\$ 250$ of farm products. About two-thirds of these worked off-farm. the majority worked away 100 days or more.

\section{FARMERS WORKING 100 DAYS OR MORE OFF-FARM}

More than one-fourth of the farmers in every county had 100 days or more of work off-farm. (Map 8). In 12 counties 50 per cent or more of the farmers worked away at least 100 days. These counties extended from the Northern Panhandle to the southern border. None of the counties on the eastern border had so high a proportion. Jefferson County with 26 per cent, had the smallest percentage of farmers working offfarm 100 days or more. Hancock had the largest percentage, with more than three-fourths of the farmers working away from the farm 100 days or more.

There was quite a variation among counties in the proportion of farmers working off the farm. These counties with high proportions of farmers working 100 days or more off the farm tended to be in areas with greater industrial and mining opportunities. There were two conditions which probably contributed to a low proportion of farmers working 100 days or more off-farm. Jefferson, Grant, Hardy, and Pendleton counties had low percentages of farmers working off-farms; this was probably influenced by the high proportion of commercial farms. Tucker, Gilmer, and Braxton counties also had low proportions. However, this was probably influenced by the lack of opportunity for off-farm employment.

\section{CHANGES IN AMOUNT OF OFF-FARM WORK}

Off-farm work increased in importance from 1930 to 1954 (Table 4). In 1930,47 per cent of the operators had some work off-farm. By 1954 this had increased to 57 per cent. However, the most important change came about in the number of days of off-farm work. In 1930, 14 per cent

Table 4. Proportion of Farmers by Numiber of Days of Work Off-Farm, West Virginia, 1930-1954*

\begin{tabular}{|c|c|c|c|c|c|c|}
\hline $\begin{array}{c}\text { DAYS WORKED } \\
\text { OFF-FARM }\end{array}$ & 1930 & 1935 & 1940 & 1945 & 1950 & 1954 \\
\hline & & & Hercen & farmers & & \\
\hline 1 to 49 & 13 & 14 & 6 & 4 & 7 & 8 \\
\hline 50 to 99 & 8 & 10 & 6 & 3 & 6 & 6 \\
\hline 100 to 199 & 12 & 11 & 16 & $\tau$ & 15 & 11 \\
\hline 200 and over & 14 & 10 & 18 & 33 & 28 & 32 \\
\hline 1 or more & $\overline{47}$ & $\overline{45}$ & $\overline{46}$ & $\overline{47}$ & $\overline{56}$ & $\overline{57}$ \\
\hline
\end{tabular}

* [. S. Bureau of Census, C. S. Census of Agriculture, 195 t, Vol. 1. Pt. 15, pp. 323. 


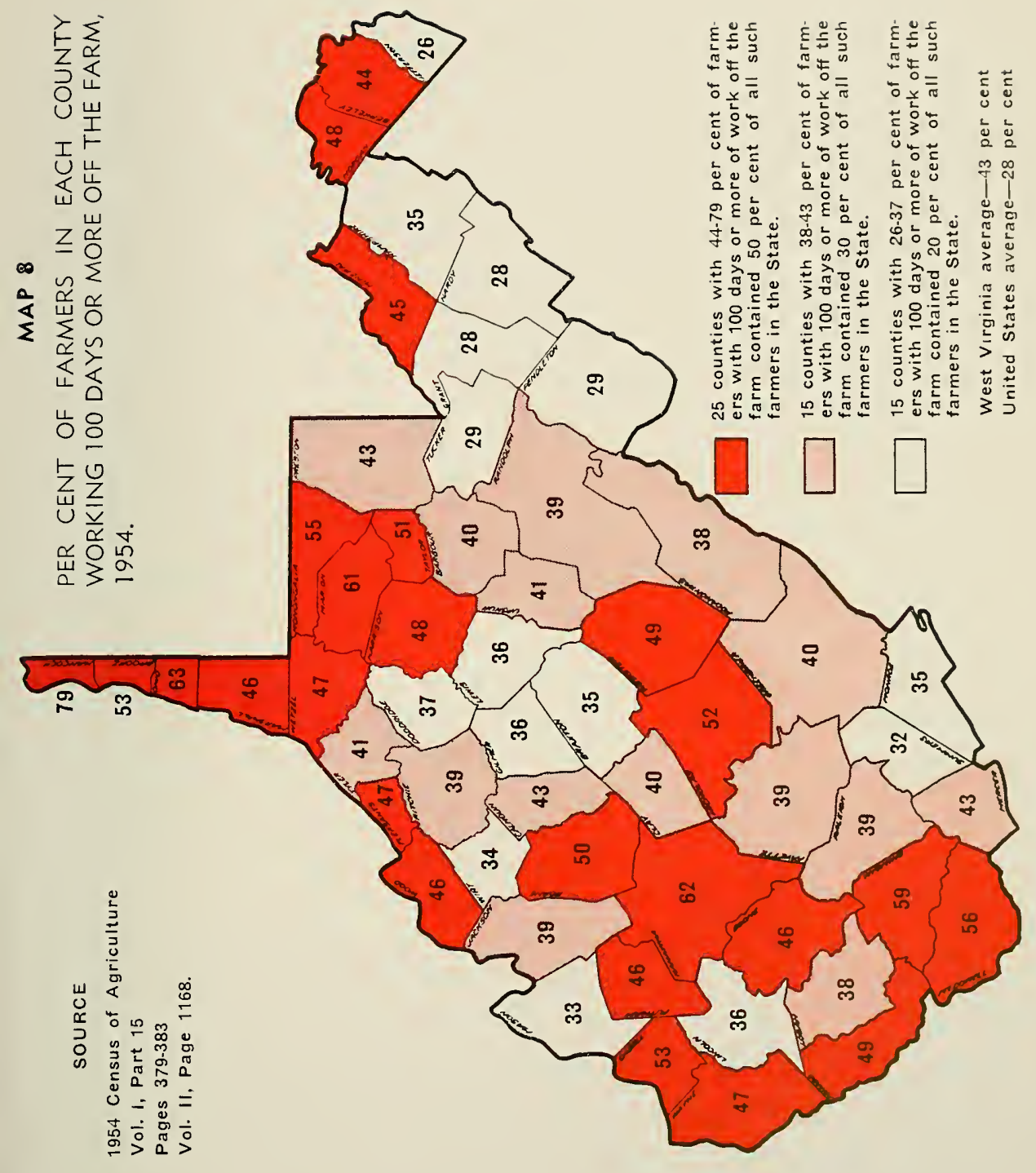


of the operators worked 200 days or more off-farm. By 1954. this proportion was increased to 32 per cent.

\section{Low-Income Farmers}

Many farmers in N'est Virginia have low incomes. The number with low incomes is influenced by the classification that is used. In this comparison, farmers were considered to have low incomes if the sale value of their farm products was less than $\$ 1,200$, if the farmers worked off the farm less than 100 days, and if the income from off-farm work was less than the value of farm sales. ${ }^{6}$ On this basis, 43 per cent of W'est Virginia famers had low incomes. By comparison, the average in the United States was 5 per cent.

The distribution of low-income farms varied considerably among counties (Map 9). None was in Hancock County; Raleigh County had 1,191. Summers had the largest proportion, with 62 per cent of its farms classified as low-income farms.

Twelve of the thirteen comties with less than 33 per cent of their farms in this low-income group were located in the two panhandles. One-fourth of the counties had 50 per cent or more of their farms with low incomes. These counties had 38 per cent of all the low-income farms in the State. Trenty-one counties contained more than 50 per cent of all these low-income farms.

\section{Sources of Farm Income}

The gross value of agricultural production in West Virginia was about $\$ 150$ million in 1957 (Table 5). Seventy-three per cent of this came from sales. Products produced on the farm and used in the home accounted for 26 per cent, and government payments provided the balance.

\section{LIVESTOCK INCOME}

Livestock and livestock products represent the major portion of the income-80 per cent of the total cash receipts and 74 per cent of the value of receipts plus produce used in the home.

Livestock sales came from a number of sources. Poultry and poultry products provided 28 per cent of all farm sales. Within the poultry group, chicken broilers were most important and eggs were second.

${ }^{6}{ }^{C}$. S. Bureau of Census, U. S. Census of Agriculture, 1954, Vol. I, 1t. 15. pp. 379-3S4.

Low-income farms are Class VI (line 15), part-time farms (line 19) and rural resident farms (line 21) minus non-commercial farmers who worked 100 days or more olf-farm. Non-commercial farms were determined by subtracting from the total number of farmers working 100 days or more off-farm (line $\$ 6$ ). the number of commercial farmers working 100 days or more oli-farm (U. S. Census of Agriculture, 1950, Vol. 1, pt. 15. pp. 422-430, line $1 \pm$ ). 


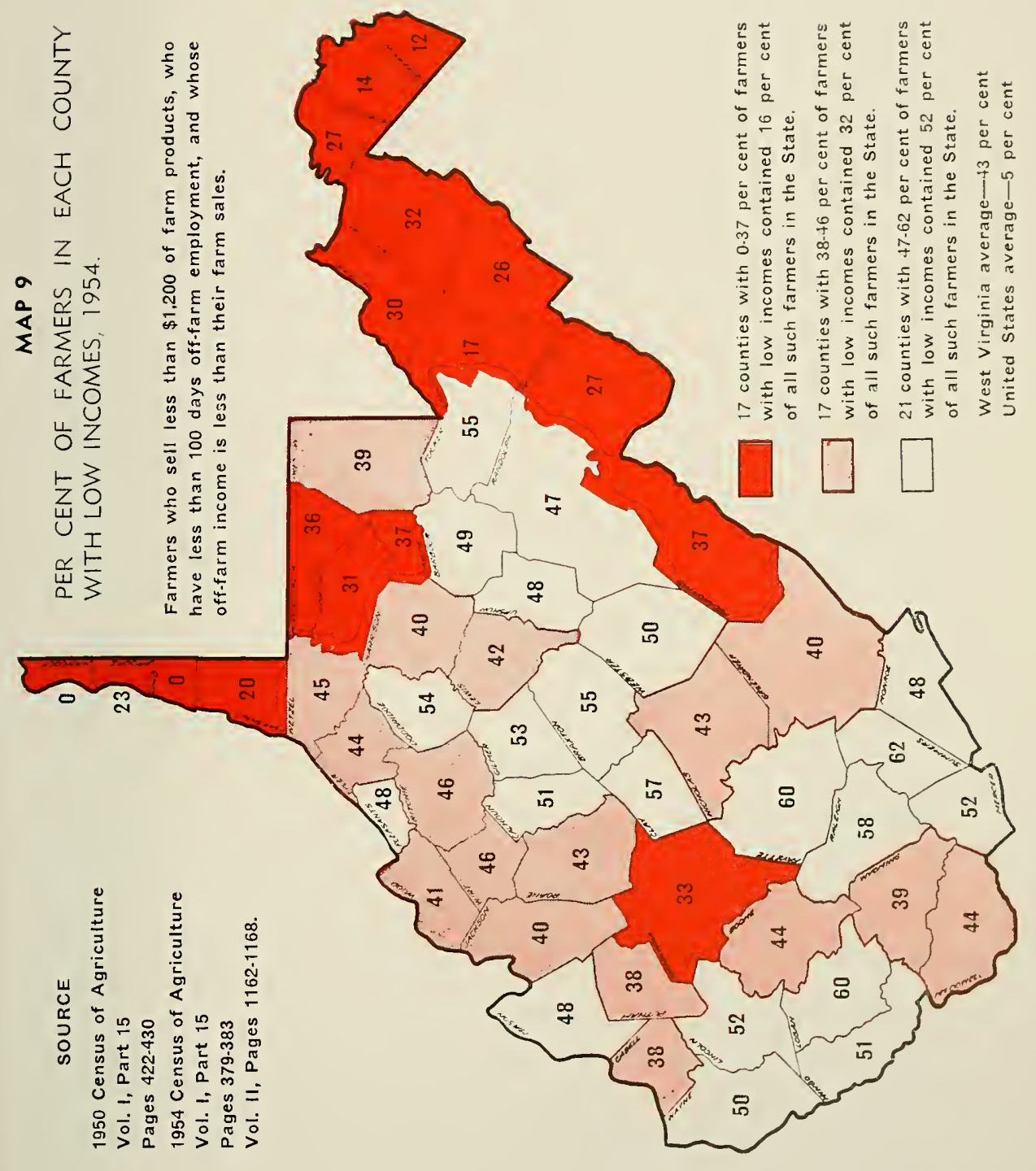


Table 5. Agricultural Income By Sources to all Farmers, 1957*

\begin{tabular}{|c|c|c|c|}
\hline SOURCES OF INCOME & $\begin{array}{c}\text { INCOME IN } \\
1000 \text { DOLLARS }\end{array}$ & $\begin{array}{c}\text { PER Cent } \\
\text { OF CASH } \\
\text { RECEIPTS }\end{array}$ & $\begin{array}{c}\text { Per Cent } \\
\text { of Total } \\
\text { Value } \\
\end{array}$ \\
\hline Dairy products .................................... & 24,698 & 22.3 & \\
\hline Dairy cattle and calves** ......... & 7,051 & $6 .+1$ & \\
\hline Other cattle and calves** & 16,453 & 14.9 & \\
\hline Hogs ................................................... & 3,700 & 3.3 & \\
\hline Sheep and lambs ............... & 3,394 & 3.1 & \\
\hline Wool (.................................. & $94 \overline{7}$ & .9 & \\
\hline Broilers & 15,904 & 14.4 & \\
\hline Eggs ............................ & 9,904 & 9.0 & \\
\hline Turkeys ...... & 4,773 & 4.3 & \\
\hline Chickens ................................ & 497 & .4 & \\
\hline Other livestock & 853 & .8 & \\
\hline All livestock and livestock products & 88,174 & 79.8 & 58.1 \\
\hline Tobacco & 1,950 & 1.8 & \\
\hline Corn & 1,545 & 1.4 & \\
\hline Hay & 1,447 & 1.3 & \\
\hline Wheat & 583 & .5 & \\
\hline 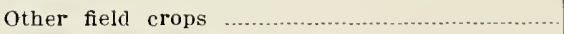 & 1,271 & 1.2 & \\
\hline Apples & 7,414 & 6.7 & \\
\hline 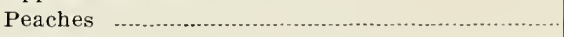 & 924 & .8 & \\
\hline Other fruits aud nuts ................ & 356 & .3 & \\
\hline Farm woodlot products ....... & 3,392 & 3.1 & \\
\hline Greenhouse and nursery .... & 3,463 & 3.1 & \\
\hline 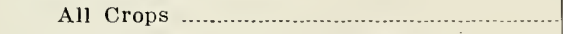 & 22,345 & 20.2 & 14.7 \\
\hline Total cash receipts from marketing .................. & 110,519 & 100.0 & 72.8 \\
\hline Livestock and products used at home & 23,386 & & 15.4 \\
\hline Crops used at home & $15,2+1$ & & 10.1 \\
\hline Total value of home consumption .............. & 38,627 & & \\
\hline 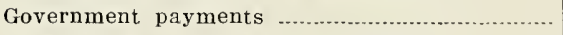 & 2,619 & & 1.7 \\
\hline Total value of agricultural production. & 151,765 & & 100.0 \\
\hline
\end{tabular}

*The Farm Income Situation, USDA, AMS, FIS-170, Sept. 1958, pp. 34, 52 and 61.

**Cash receipts from the sale of cattle and calves as reported in the Farm Income Situation were $\$ 23,504,000$. An estimated 30 per cent of the cattle and calves sold in West Virginia are dairy or predominately of dairy breeding. See Hutson, W. S., Livestock Marketing Practices of West Virginin Farmers, W. Va. Univ. Agr. Exp. Sta. Bul. 384, Dec. 1955 , p. 19.

Dairy cattle and dairy products accounted for 29 per cent of the sales. When compared with individual classes of livestock and livestock products, dairy products represented the most important single source of cash sales. Beef cattle sales were about 15 per cent of the cash sales. Sheep and hogs each accounted for about 4 per cent of the cash sales.

\section{CROP INCOME}

The primary use of crops was for livestock feed. Consequently, the value of crop sales is relatively low. The crop with the largest proportion of sales in 1957 was apples, representing about 7 per cent of all farm sales. Farm woodlot products accounted for 3 per cent. The sales from greenhouses and nurseries accounted for another 3 per cent.

Data regarding gross sales are available on a county basis from the 1954 Census of Agriculture. Even though they are given in less detail 
for commodities, there is sufficient data to classify counties on the basis of their principal source of sales.

\section{MAJOR SOURCES OF INCOME}

Leading types of agricultural production vary among counties, but areas of concentration of specific types exist (Map 10). In this classification poultry includes the sale of all poultry and poultry products. Dairy represents only the sale of milk and cream. Livestock comprises dairy animals, beef, sheep, hogs, horses and mules. Fruit comprises both small and large fruits. Field crops represent all crops except vegetables and potatoes. Horticulture specialities include nursery sales.

Livestock and dairy sales provided the highest proportion of gross sales of farm products in 67 per cent of the counties. Livestock sales alone were the leading source in 51 per cent of the counties. 'These counties are located in an area running generally from the northwestern border across to the southeastern borcler of the State. Dairy products were most important in nine counties. Six of these are located on the western border.

Poultry sales ranked first or second in 42 per cent of the counties. They were the leading source of sales in eight counties, five of which are located in the Eastern Panhandle, and three in the southern part of the State.

Fruit production, primarily apples and peaches, was in the first or second place in 15 per cent of the counties. It led in five counties. Three are in the Eastern Panhandle, and the other two are widely scattered.

\section{Farm Land and Its Relation to Income}

Farm sales were closely related to the size of farm (Table 6). Farms with sales of less than $\$ 250$ averaged 12 acres of cropland, those with sales of $\$ 2,500$ to $\$ 5,000$ averaged 64 acres, and farms with sales of $\$ 25,000$ and more averaged 165 acres in cropland. Open permanent pasture acreages in these three income groups averaged 12, 89, and 197 respectively. Their total woodland averaged 26, 97, and 208 acres.

Not only did the farms with largest incomes have largest acreages, but they also had largest proportions of the acreage in cropland. The relative increase was even greater in the proportion of cropland harvested for crops. Consequently, the opposite situation occurred with cropland pastured and cropland not harvested.

Farmers in all economic classes pastured about half to 60 per cent of their farm acreage. Cropland pasture accounted for less than 10 per cent of the land in each economic class. The proportion of the farms 


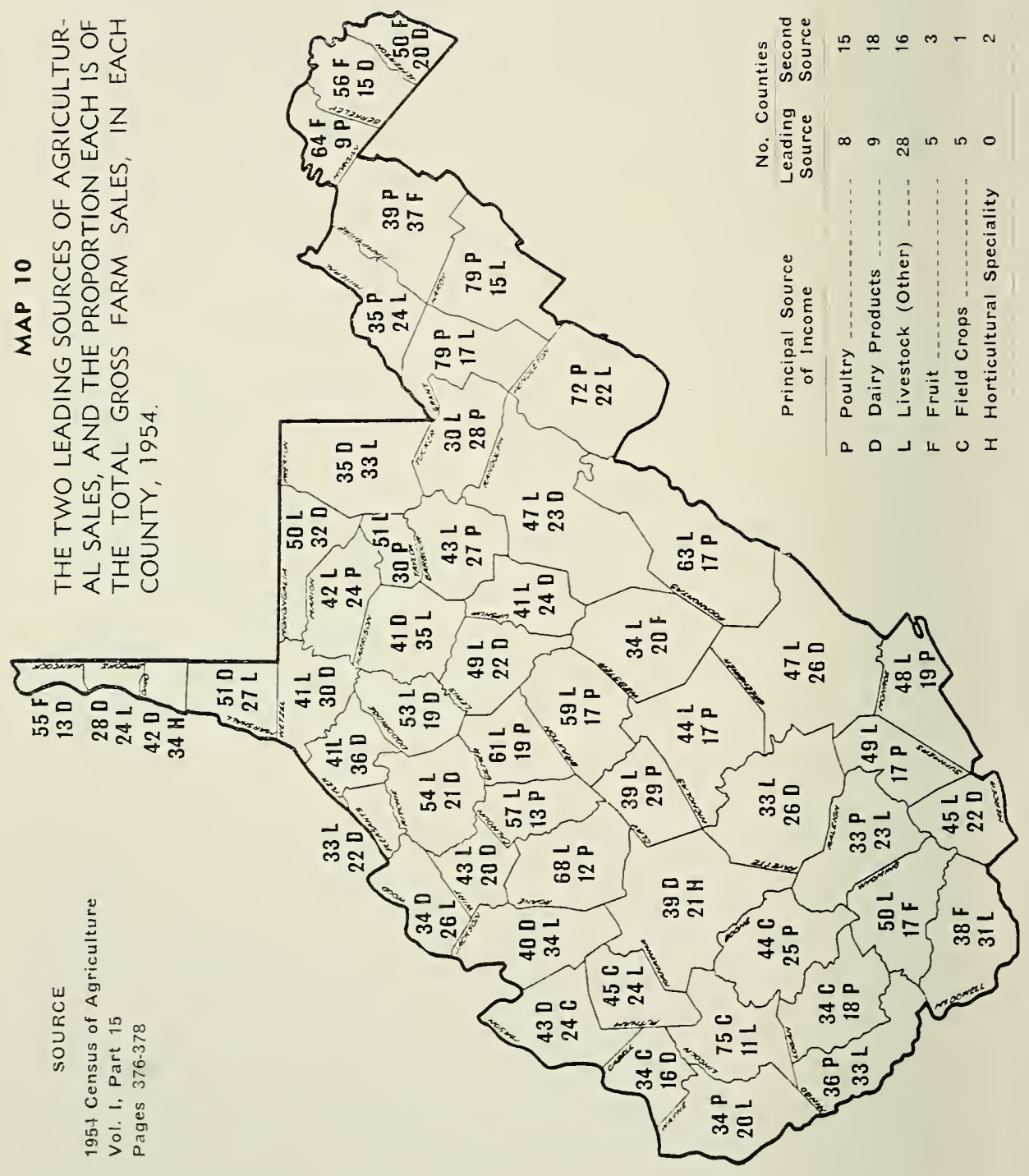


Table 6. Proportion of Land in Major Land Uses By Econonic Class OF FARMS, IIEST VIRGINia, 1954.*

\begin{tabular}{|c|c|c|c|c|c|c|c|c|}
\hline \multirow[b]{2}{*}{ LAND USE } & \multicolumn{8}{|c|}{ ECONOMIC Class OF FARMS } \\
\hline & 1 & I1 & 111 & IV & $\mathrm{V}$ & $\mathrm{V} 1 * *$ & $\begin{array}{l}\text { PART- } \\
\text { TIME** }\end{array}$ & $\begin{array}{l}\text { RIRAL } \\
\text { RESIDEAT }\end{array}$ \\
\hline IOTAL ACRES .... & 585 & 399 & 289 & $\begin{array}{c}256 \\
\text { Per Cent }\end{array}$ & $\begin{array}{l}181 \\
\text { of Land }\end{array}$ & 125 & 102 & 52 \\
\hline $\begin{array}{l}\text { Cropland } \\
\text { harvested } \\
\text { Cropland not }\end{array}$ & 21 & 19 & 19 & 17 & 16 & 15 & 15 & 9 \\
\hline $\begin{array}{l}\text { Cropland not } \\
\text { harvested } \\
\text { Cropland }\end{array}$ & 2 & 1 & 1 & 1 & 2 & 3 & 2 & 6 \\
\hline $\begin{array}{l}\text { pasture } \\
\text { Total }\end{array}$ & 5 & 6 & 8 & 7 & 7 & 7 & 8 & S \\
\hline $\begin{array}{c}\text { cropland } \\
\text { Open permanent }\end{array}$ & 28 & 26 & 28 & 25 & 25 & 25 & 25 & 23 \\
\hline $\begin{array}{r}\text { pasture } \\
\text { Woodland }\end{array}$ & 33 & 35 & 38 & 34 & 34 & 31 & 29 & 23 \\
\hline $\begin{array}{l}\text { pastured } \\
\text { Total }\end{array}$ & 12 & 18 & 14 & 17 & 17 & 20 & 20 & 17 \\
\hline $\begin{array}{c}\text { pastured } \\
\text { Woodland not }\end{array}$ & 50 & 59 & 60 & 58 & $5 s$ & 58 & 57 & 48 \\
\hline $\begin{array}{l}\text { pastured } \\
\text { Total }\end{array}$ & 24 & 19 & is & 21 & 22 & 22 & 23 & 33 \\
\hline $\begin{array}{l}\text { woodland ...... } \\
\text { Other }\end{array}$ & 36 & 37 & 32 & 38 & 39 & 42 & 43 & 50 \\
\hline land ................ & 3 & 2 & 2 & 3 & 2 & 2 & 3 & 4 \\
\hline
\end{tabular}

*U. S. Bureau of Census, U. S. Census of Agriculture, 1954, Vol. I. pt, 15, pp. 430-431.

**Farms with sales of $\$ 250$ to $\$ 1,199$ were Class VI provided the operator had less than 100 days of off-farm work and income of the operator and members of his family from non-farm sources was less than the value of all iarm products sold; the other farms in this income group were elassified as part-time.

in woodland pasture was about two to three times greater than the proportion in cropland pasture for each economic class of farms. Except on farms with the lowest incomes, the acreage in open permanent pasture was larger than the combined acreage of cropland and woodland pasture.

Farms with sales of $\$ 1,200$ or more had woodland and accounted for 32 to 40 per cent of the acreage. Farms with lower incomes had a larger proportion of woodland.

\section{AMOUNT OF CROPLAND}

In the United States, 40 per cent of the farm land was classified as cropland, but in West Virginia only 25 per cent of the farm land was so designated (Map 11). Only six states had a smaller proportion of the farm acreage in cropland than West Virginia. Other than Florida the states were western mountain states. They were Montana, Nevada. Wyoming, New Mexico, and Arizona.

Although 25 per cent of the farn land in W'est Virginia wals classified as cropland, only 15 per cent was in cropland harrested. This includes

${ }^{\top}$ U. S. Bureau of Census, U. S. Census of Agriculaure, 1954, Vol. 11. P. 40. 
land from which crops were harvested; land from which hay was cut; and acreages in small fruits, orchards, vineyards, nurseries, and greenhouses. Seven per cent of the farm acreage was in cropland pasture. The other 3 per cent was in cropland not used for production. This was idle land, land in soil improvement crops only, land on which crops failed, and land seeded for harvest the following year.

Twenty counties, or 36 per cent of the total, contained more than half the farm acreage classified as cropland. These counties are located in many parts of the State. Counties containing the smallest proportion of the State's total cropland are also scattered about the State.

Jefferson County, with 64 per cent of its farm acreage in cropland, had the highest proportion, and Pendleton County, with 11 per cent, had the smallest proportion.

\section{AMOUNT OF PASTURE LAND}

Pasture land in West Virginia accounted for 55 per cent of the farm land. ${ }^{s}$ This percentage was practically the same as the United States average. The proportion of the acreage in cropland pasture was slightly higher in West Virginia than it was in the Nation. The proportion of woodland pastured was 17 per cent compared with the United States average of 10 per cent of all land in farms. Only nine states had a higher proportion of pastured woodland than West Virginia. In contrast, the proportion of land in open permanent pasture in West Virginia was below the national average, being 31 per cent in West Virginia and 40 per cent for the Nation. No state adjacent to or east of the Mississippi River had so high a proportion of land in open permanent pasture as did West Virginia. This pasture, which includes pastured rough and brush land and any other pasture not woodland or cropland, accounted for most of the land pastured in the State.

In West Virginia, one-fourth of the counties had half of the acreage in permanent pasture (Map 12). Most of these counties are in the eastern and the north central parts of the State. Farms with the smallest proportion of the State's permanent pasture land are in the Northern Panhandle, southwestern and south central parts of the State.

Harrison County, with 58 per cent of all farm land in open permanent pasture, had the highest proportion of farm land pastured. Mingo and McDowell counties had the least, I per cent each.

\section{AMOUNT OF WOODLAND}

In the United States, 17 per cent of the farm land was classified as woodland, but in West Virginia 41 per cent of the farm land was woodland.

slbid. 


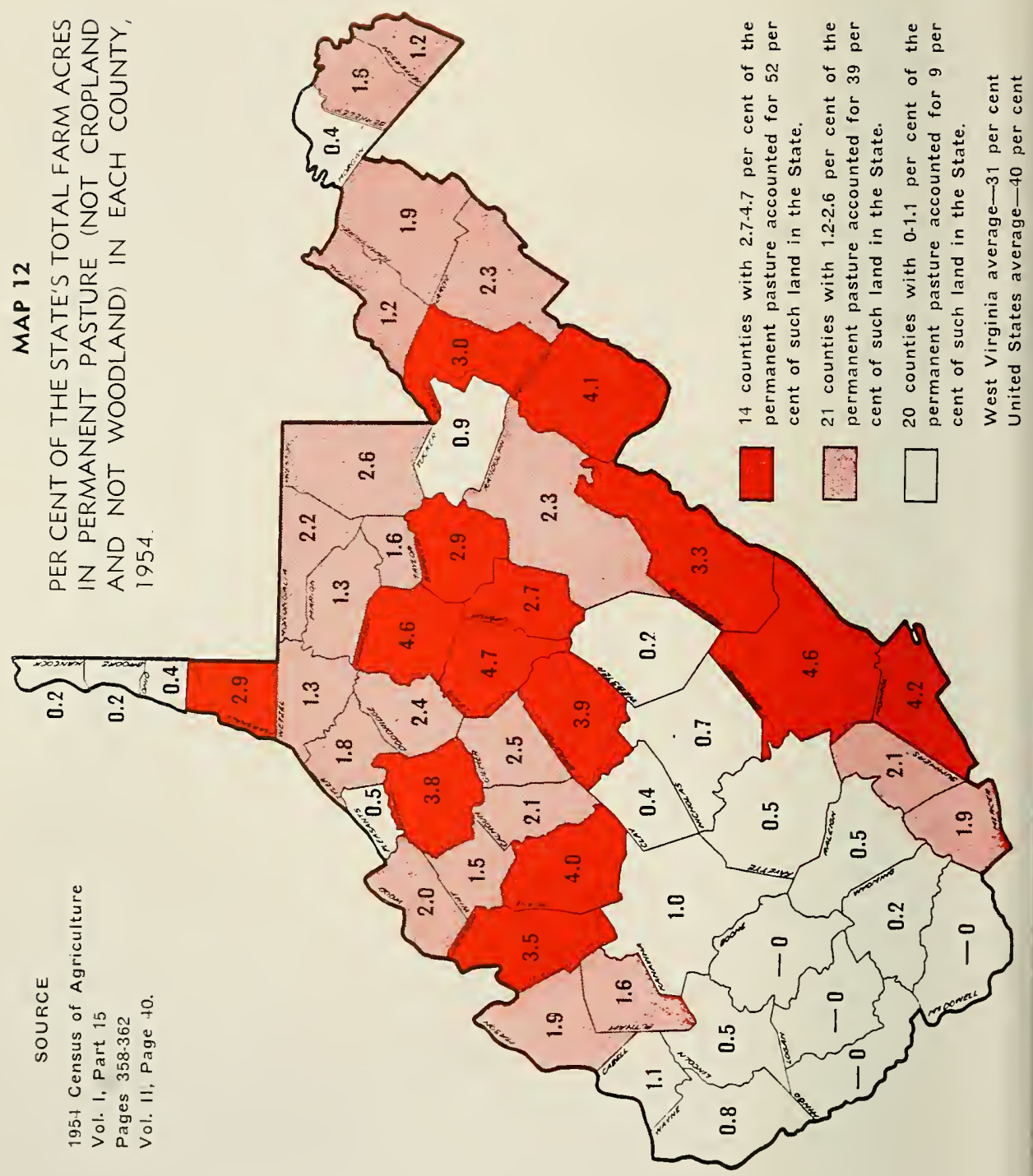


In West Virginia, 29 per cent of the counties contained half of the woodland acreage (Map 13). More than half of this group of counties are in eastern West Virginia.

Jefferson County, with 7 per cent, had the lowest proportion of farm land in woods. By contrast, this county had the largest proportion of the farm acreage in cropland. Boone County, with 75 per cent, had the largest proportion of the farm land in woods.

\section{Livestock Sales and Their Relation to Income}

The income from the sales of livestock, including farm animals and poultry and their products, is very important to West Virginia farmers. On farms with sales of all farm products of $\$ 25,000$ or more, the income from this source was about 50 per cent of all sales (Table 7). On farms with lower volume of sales, the relative importance of livestock income was greater. Those farms with gross sales of $\$ 1,200$ to $\$ 25,000$ had income from livestock sources which represented 80 to 90 per cent of their farm income.

The income from poultry and poultry products was more important than the income from other livestock on farms with sales of $\$ 25,000$ or more. These farms averaged about $\$ 19,000$ of income from poultry and poultry products (Table 8 ). This was 69 per cent of all their livestock sales. On these large farms, only Il per cent of the sales came from dairy products. The remaining 20 per cent came from all other livestock sources.

The income from the sale of farm animals such as cattle, hogs, and sheep was more important than the combined income from poultry, poultry products, and dairy products on farms with a small volume of sales. Income from the sale of these animals was 69 per cent of all livestock income on part-time and residential farms. Even though these animals represented the largest proportion of sales, the value of these was small, averaging $\$ 291$ on part-time farms and only $\$ 35$ on residential farms.

The relative importance of poultry and poultry products was associated with the volume of farm sales. Poultry was relatively more important on farns with a large volume of sales than on farms with a small volume of sales. On farms with gross sales of $\$ 25,000$ or more, poultry sales represented 69 per cent of all lirestock income. Those farms with sales of $\$ 5,000$ to $\$ 10,000$ had poultry sales equal to a third of all livestock sales. On farms with gross sales under $\$ 250$, poultry income ras only 21 per cent of all livestock income. 


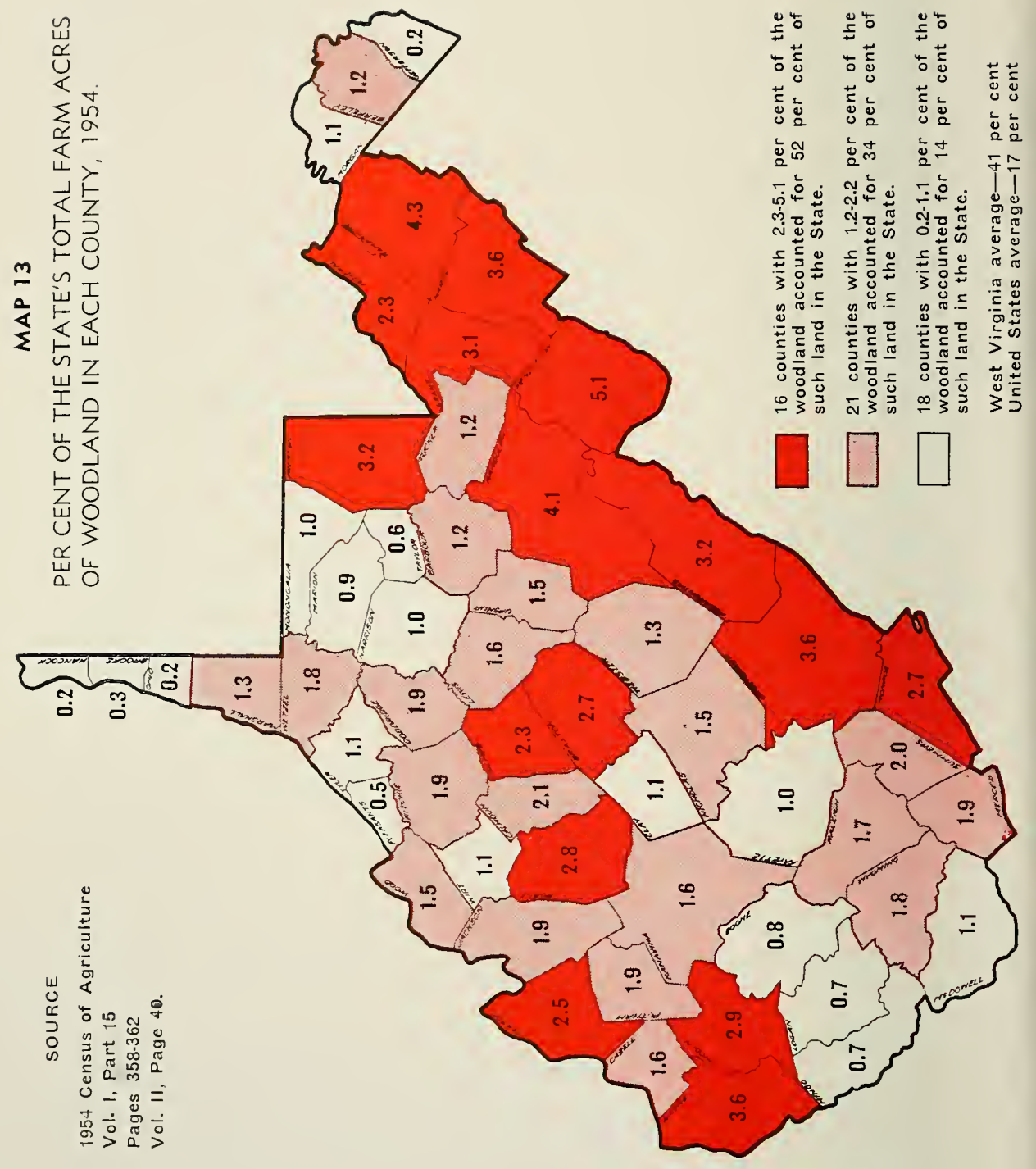


Table 7. Distribution of Sales of Livestock and Livestock Pronlcts, By Economic Classes, Mest Virginia, 1954.**

\begin{tabular}{|c|c|c|c|c|c|}
\hline \multirow[b]{2}{*}{$\begin{array}{l}\text { ECONOAIC } \\
\text { ClaAs }\end{array}$} & \multirow[b]{2}{*}{$\begin{array}{l}\text { VALUE OF ALL } \\
\text { SALES PER FARM }\end{array}$} & \multirow{2}{*}{$\begin{array}{l}\text { PER CENT ALL } \\
\text { LiVESTOCK } \\
\text { SALES ARE OF } \\
\text { ALL SALES }\end{array}$} & \multicolumn{3}{|c|}{ Per Cent of All Livestock Sales } \\
\hline & & & $\begin{array}{c}\text { POLltry \& } \\
\text { POLltry } \\
\text { Prodects }\end{array}$ & $\begin{array}{c}\text { DAIRY } \\
\text { PRODLCTS }\end{array}$ & $\begin{array}{c}\text { GTHER } \\
\text { LIVESTOCK } \\
\text { \& ProdtCTS }\end{array}$ \\
\hline 1 & $\$ 25,000$ or more & 49 & 69 & 11 & 20 \\
\hline II. & 10,000 to 24,999 & st & 42 & 32 & 26 \\
\hline III & 5,000 to 9,999 & ss & 35 & 34 & 31 \\
\hline IV & 2,500 to 4,999 & 85 & 24 & 32 & +4 \\
\hline $\mathrm{V} \ldots$ & 1.200 to 2.499 & 80 & 20 & 20 & (ji) \\
\hline $\mathrm{VI} * * \quad \ldots \ldots \ldots$ & 250 to 1,199 & 75 & 18 & 18 & 64 \\
\hline Part-Time** & 250 to 1,199 & 75 & 18 & 13 & $1 ; 9$ \\
\hline Residential .... & Less than 250 & 73 & 21 & 10 & 69 \\
\hline
\end{tabular}

*L. S. Bureau of Census, L. S. Census of Agriculture, 1954, Vol. II, p. 1231.

** See footnote to Table 1 .

Table 8. Value of Livestock and Livestock Prodlcts Sold Per Farm, By Econonic Class of Faris, West Virginia, 1954.**

\begin{tabular}{|c|c|c|c|c|c|}
\hline \multirow[b]{2}{*}{$\begin{array}{c}\text { ECONOMIC } \\
\text { CLASS }\end{array}$} & \multirow[b]{2}{*}{$\begin{array}{c}\text { VALLE OF ALL } \\
\text { SALES } \\
\text { PEK FARMI }\end{array}$} & \multicolumn{4}{|c|}{ Livestock axd Livestock Product Sales Per Farm } \\
\hline & & $\begin{array}{l}\text { TOTAL } \\
\text { SALES }\end{array}$ & $\begin{array}{l}\text { Potltry \& } \\
\text { POULTRy } \\
\text { Prodicts }\end{array}$ & $\begin{array}{c}\text { DAIRY } \\
\text { PRODTCTS }\end{array}$ & $\begin{array}{c}\text { OTHER } \\
\text { LIVESTOCK } \\
\text { \& PRODUCTS }\end{array}$ \\
\hline I & $\$ 25,000$ or more & $\begin{array}{l}\text { Dollars } \\
27,2 \pm 8\end{array}$ & $\begin{array}{l}\text { Dollars } \\
18,938\end{array}$ & $\begin{array}{c}\text { Dollars } \\
3,013\end{array}$ & $\begin{array}{c}\text { Dollars } \\
5,297\end{array}$ \\
\hline II & 10,000 to 24,999 & 13,069 & $5,+97$ &,+ 165 & 3,407 \\
\hline I11 & 5,000 to 9,999 & 6,196 & 2,155 & $2,11 \mathrm{~s}$ & 1.923 \\
\hline IV & 2,500 to 4,999 & 3,057 & 737 & 976 & 1.344 \\
\hline V & 1,200 to 2,499 & 1,381 & 282 & 273 & 826 \\
\hline $\mathrm{VI} \mathrm{I}^{* *}$ & 250 to 1,199 & 487 & 88 & ST & 312 \\
\hline Part-Time ${ }^{* *}$ & 250 to 1,199 & 421 & $7 t$ & 56 & 291 \\
\hline Residential ..... & Less than 250 & 51 & 11. & 5 & 35 \\
\hline
\end{tabular}

*U. S. Bureau of Census, U. S. Census oî Agriculture, 1954, Vol. II, pp. 1165 and 1223. ** See footnote to Table 1 .

Cattle, hog and sheep sales were about the reverse of the relationship between poultry sales and all farm sales. Cattle, hog and sheep sales were relatively more important on farms with a small volume of sales and relatively less important on farms with a large volume of sales. Farms with gross sales under $\$ 250$ had 69 per cent of all livestock sales from these animals. On farms with sales of $\$ 25,000$ or more, these animals accounted for only 20 per cent of all livestock sales.

Sales of dairy products were relatively more important on farms with a medium volume of sales than on those with a large or small volume of sales. On farms with sales under $\$ 250$ and on those with sales over $\$ 25,000$, dairy products represented about 10 per cent of all sales. The importance of dairy product sales increased from these extremes. Those farms having 34 per cent all livestock sales from dairy products had gross sales of $\$ 5,000$ up to $\$ 10,000$. 


\section{DAIRY}

Dairying is the leading source of agricultural income in West Virgina (see Table 5). About 99 per cent of all agricultural sales in 1957 came from the clairy business. This included 22 per cent from dairy products and an estimated 7 per cent from dairy animals.

In the State, 77 per cent of all farmers kept one or more milk cows (Map 14). However, only 10 per cent of the farmers sold whole milk.

Dairying is concentrated in several areas of the State. Fifty per cent of the whole milk sold was produced in 13 per cent or seven counties. Two of these are adjacent, and the rest are wiclely scattered. Another 13 per cent of the counties procluced 22 per cent of the whole milk sold, and only two of these are adjacent. Another 22 per cent of the counties each had whole milk sales that were from 1 to 2 per cent of the State total. These too are widely scattered. The remaining 52 per cent of the counties had cumulative milk sales of only 12 per cent of the State total.

Jefferson was the leading county in milk sales and was second in importance in the proportion of farmers selling whole milk. It had 10 per cent of all milk sales in the State; and 46 per cent of the farmers in the county sold milk. Marshall County had the largest proportion of dairymen, with 51 per cent selling whole milk. Five counties had 20 to 30 per cent of the farmers in each county selling whole milk. Four of these-Berkeley, Harrison, Preston, and Ohio-were leading producers. The fifth was Tucker, but the total sales from that county were relatively low.

\section{BEEF}

Sales of beef cattle and calves accounted for an estimated 15 per cent of the cash farm receipts in 1957 (see Table 5). The number of beef cows, including all cows other than milk cows, was 40 per cent of all cows that had calved (Map 15).

The principal areas of beef production were not as widely scattered as were areas of dairy production. About a fourth of the counties had more than 50 per cent of the beef cows. Most of these counties are near the eastern part of the State; the others are in the central to western part. An additional 36 per cent of the counties had 37 per cent of the beef cows. Most of these are in the north central part of the State or adjacent to counties with the largest proportion of beef cows. The remaining 38 per cent of the counties contributed little to the beef cattle industry; they had only 9 per cent of the beef cows. The largest proportion of these counties are in the Northern Panhandle and the southwestern part of the State. 


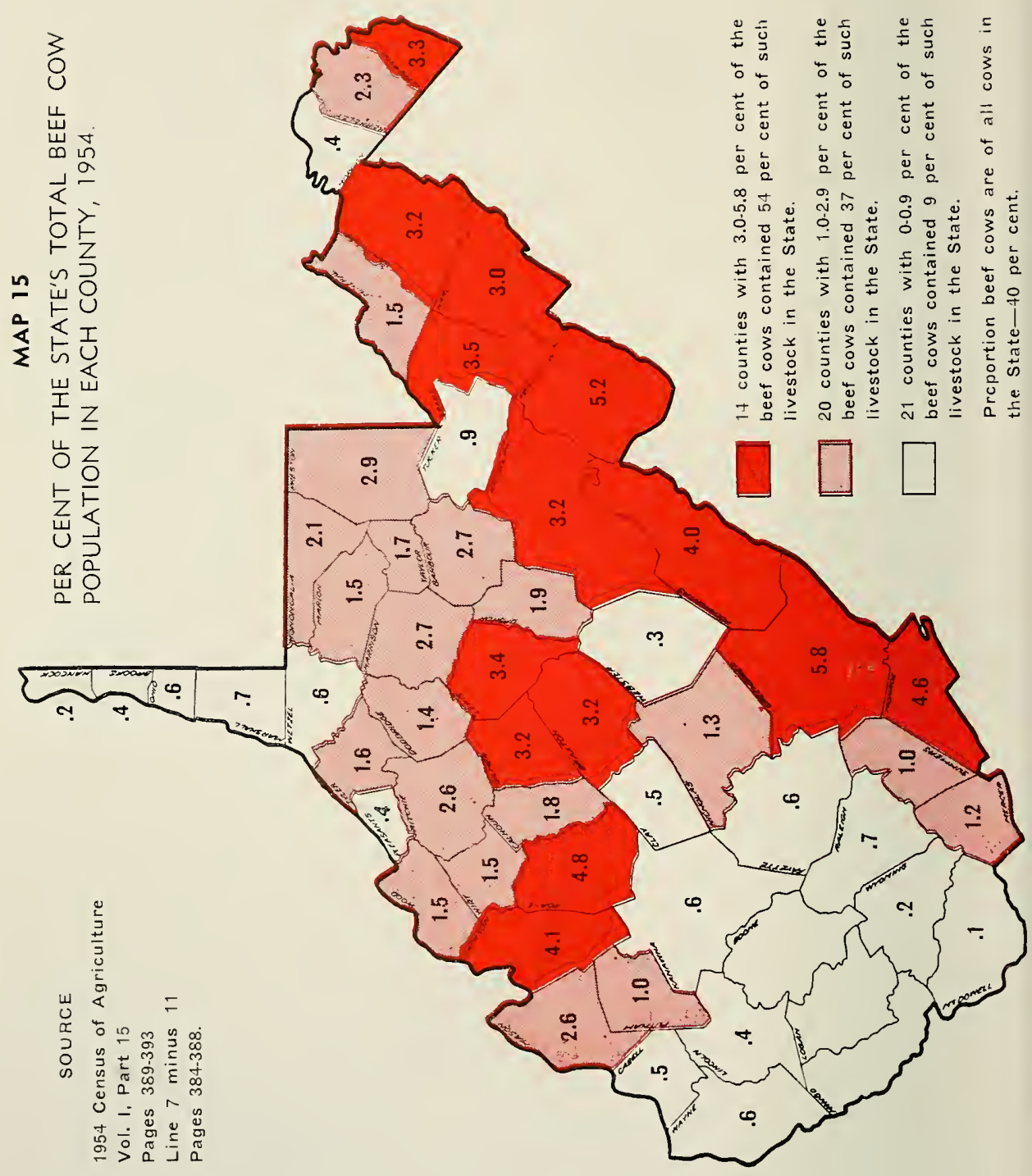


Greenbrier County contained the largest proportion of beef cows in the State. It has 3.2 per cent of all farms in the State and 5.8 per cent of the beef cows. Pendleton was second in importance, with 5.2 per cent of all beef cows. It had a smaller proportion of the farms in the State: consequently, the number of beef cows per farm in the county was greater than in Greenbrier.

\section{SHEEP}

Income from the sheep industry represented about 4 per cent of the cash receipts from all farm marketings (see Table 5). This include! 3 per cent from the sale of sheep and lambs and 1 per cent from the sale of wool. Of all farmers in the State, about 14 per cent kept ewes (Map) 16) .

Sheep production is more concentrated than beef production. About 50 per cent of the ewes were located in 7 counties. All these counties were among the leading counties in beef production. However, it took nearly twice as many of the leading beef counties to account for 50 per cent of the beef cows.

The 13 per cent of the counties that accounted for about hall the ewes are all joining counties in the Appalachian Valley and Ridge section along the eastern part of the State. Another 15 per cent of the counties, each of which account for 2 to 4 per cent of the ewes in the State, are adjacent to the major sheep area and are in the central and northern part of the State. About 25 per cent of the counties, each of which hat 1 to 2 per cent of the ewes in the State had in total about 20 per cent of all ewes. Nearly half of the counties each had less than 1 per cent of the ewes; in total these had only 8 per cent of the ewes.

Pocahontas and Pendleton were the leading counties in sheep production, each with about 24,000 ewes. In each county this represented about 10 per cent of all ewes in the State. In both counties, two-thirds of the farmers kept ewes.

The levels of concentration of ewe population and of quantities of whole milk sold were usually similar, but the areas of concentration were quite different. In each instance about 13 per cent of the counties had 50 per cent of the quantities. Each of these counties had from 4 to 11 per cent of the State total. Another 13 to 15 per cent of the counties had about 22 per cent of the quantities. Each of these counties had about 2 to 4 per cent of the State total. However, only Greenbrier was among the leading counties in both ewes and milk sales. Only four other counties were among the top two groups in both number of ewes and milk sales; these were Summers, Marshall, Monongalia, and Lewis. 


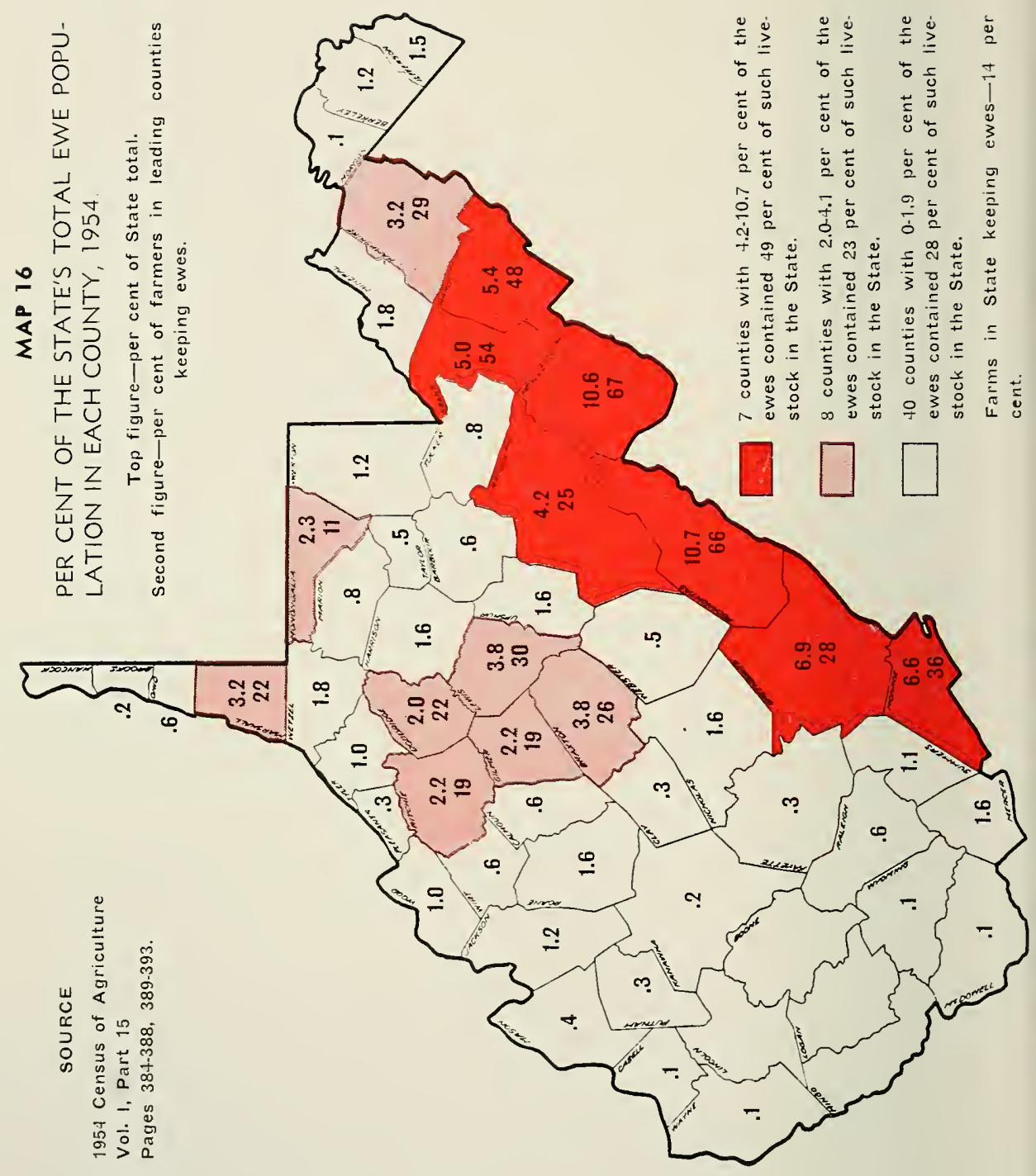




\section{HOGS}

Hog sales accounted for more than 3 per cent of the cash farm receipts in 1957 (see Table 5).

Half of the sows that farrowed in the State were in one-fourth of the counties (Map 17), mostly along the eastern sicle of the State. Another fourth of the counties had a fourth of the sows. The remaining half of the counties contained the other fourth of the sows that farrowed.

The 13 counties that contained half of the sows that farrored were also the leading counties in number of hogs and pigs on farms. These counties and two others, Roane and Mercer, contained 51 per cent of the hogs and pigs.

The number of farmers with hogs on their farms was considerably larger than the number of farmers keeping sows. In the State, 58 per cent of the farmers had hogs, but only 13 per cent had sows that farrowed. Farms with hogs and pigs averaged 4.6 head per farm. Farms with sows averaged 3.0 head per farm.

Jefferson was the leading county in sows farrowed and number of hogs, with 6 per cent of the sows in the State and a similar proportion of hogs and pigs.

\section{BROILERS}

Broiler sales accounted for 14 per cent of the cash receipts from farm marketings in 1957 (see Table 5 ). Broilers were second in importance as a source of farm sales, being exceeded by dairy products. The number of farmers raising broilers was relatively small (only 3 per cent of farmers sold broilers).

Most of the broilers are produced in a small area of the State (Map 18). Three counties in the South Branch Valley accounted for 64 per cent of the production. Another 11 counties had 28 per cent of the production. Except for one county, all of these are in the central and eastern parts of the State.

Hardy was the leading broiler county. It alone produced 2.5 per cent of the broilers. Nearly half of its farmers sold broilers. Except for the four leading counties, fewer than 10 per cent of the farmers in each county produced broilers.

\section{EGGS}

Egg sales are an important source of income. Nine per cent of all cash farm sales came from eggs in 1957 (see Table 5). The income from the sale of eggs and chickens other than broilers was about as large as the estimated income from beef cattle. 


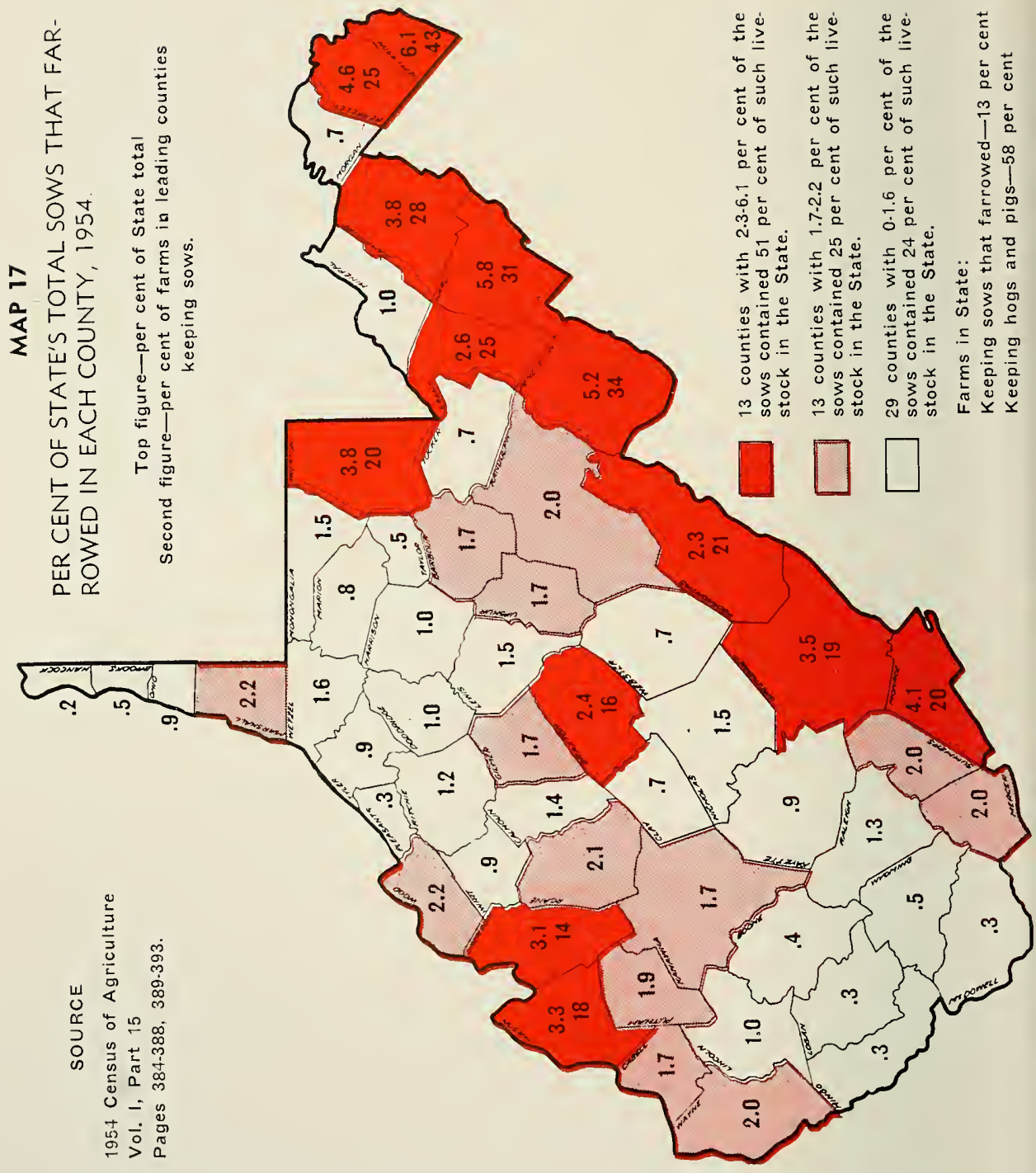


亗

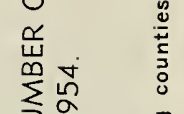

々元

步告

$\infty \backsim$

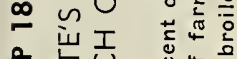

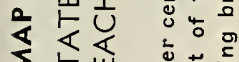

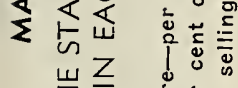

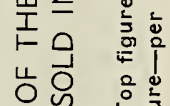

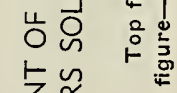

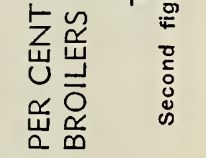
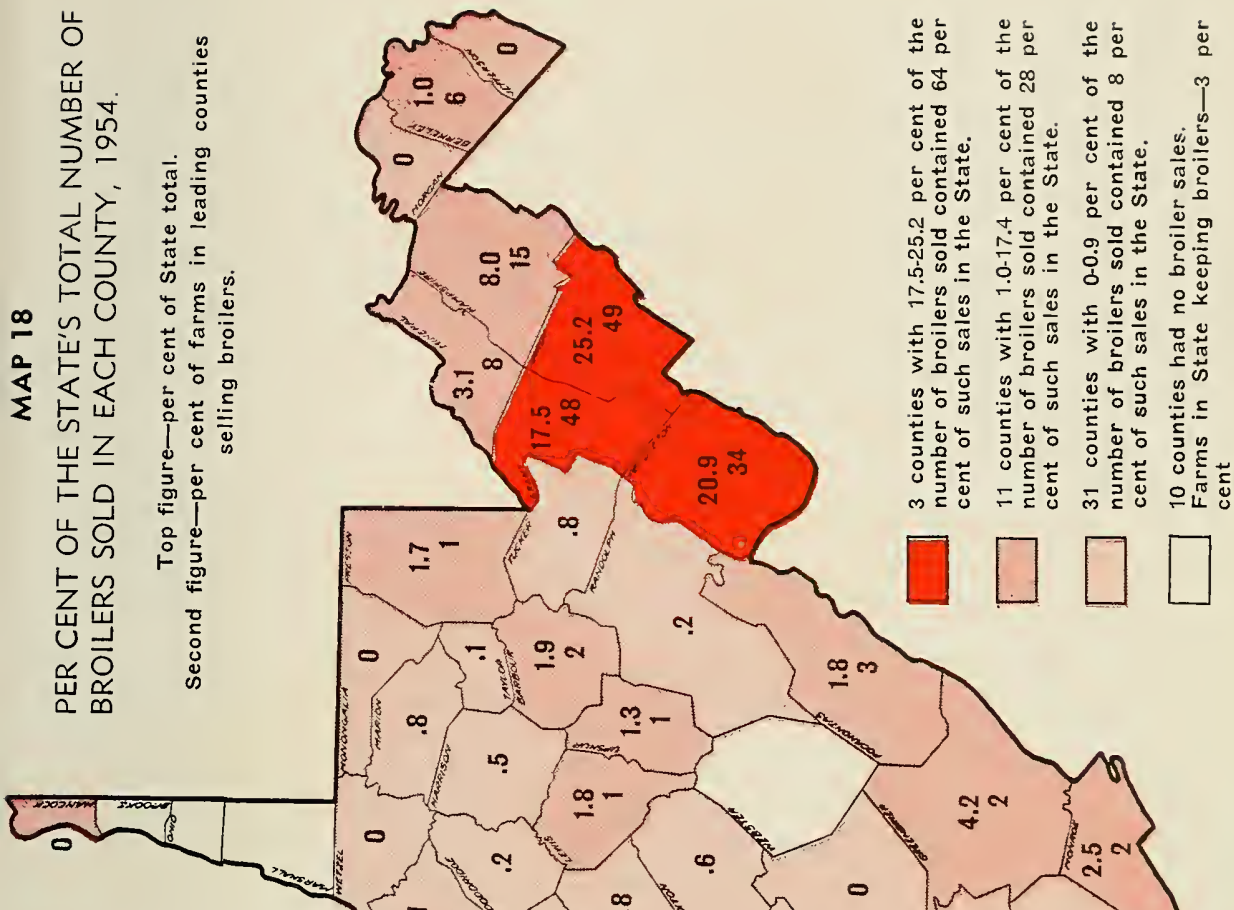

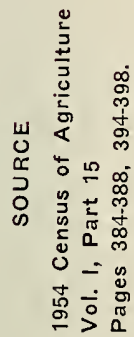

‡

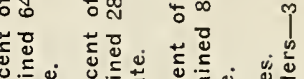

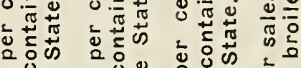

\% +

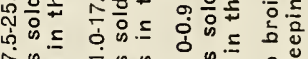

$\sim \frac{\omega}{4} \mathscr{0}$

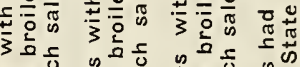

马ั

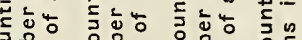

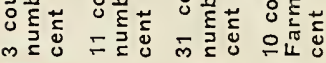


As in the case with whole milk sales, a considerably larger proportion of farmers kept the production stock than sold the product. In both cases, 77 per cent of the farmers kept chickens 4 months old and over and milk cows (Map 19). However, only 30 per cent of the farmers sold eggs.

Egg sales were scattered throughout the State. It took 29 per cent of the counties to account for half the egg sales. Most of the counties leading in egg sales were along the eastern and the western areas of the State. Another 36 per cent of the counties accounted for an additional third of the egg sales. The remaining 35 per cent accounted for only 13 per cent of the egg sales. Preston County had the largest volume of egg sales, with 4.7 per cent of the State total. This is a smaller proportion of the state total than was the case for the leading county with other important classes of livestock products.

\section{TURKEYS}

The cash receipt from turkeys was about 4 per cent of all cash receipts (see Table 5). Even though the income from turkeys was less than from broilers, a few more farmers had more turkey sales than broiler sales.

Turkey production was concentrated in the Eastern Panhandle. Two counties had more than 50 per cent of the production. Five counties had more than 90 per cent. Twenty-three counties, in various areas of the State, each produced from 0.1 to 0.9 per cent of the State's production. Each of the other 27 counties produced a few turkeys, but their combined production was less than 2 per cent of the State total.

Hardy was also the principal producer of turkeys, with about 31 per cent of all sales in the State (Map 20). This production came from 16 per cent of the farmers in the county.

\section{Relation of Purchased Feed to Livestock Sales}

The relationship between feed expenditures and sales of livestock (including poultry sales) varied considerably between counties (Map 21). In 1954, farmers in West Virginia had feed purchases that averaged 43 cents for each dollar of livestock sales.

Farmers in 29 per cent of the counties spent less than 31 cents on leed for each clollar of livestock sales. Most of these farms were in the central and northwestern parts of the State. Farmers in another 29 per cent of the counties spent from 31 to 42 cents on feed for each dollar of livestock sales. A third group of counties, equal in number to the other two groups, had feed costs of 43 to 73 cents on feed for each dollar of livesiock sales. 


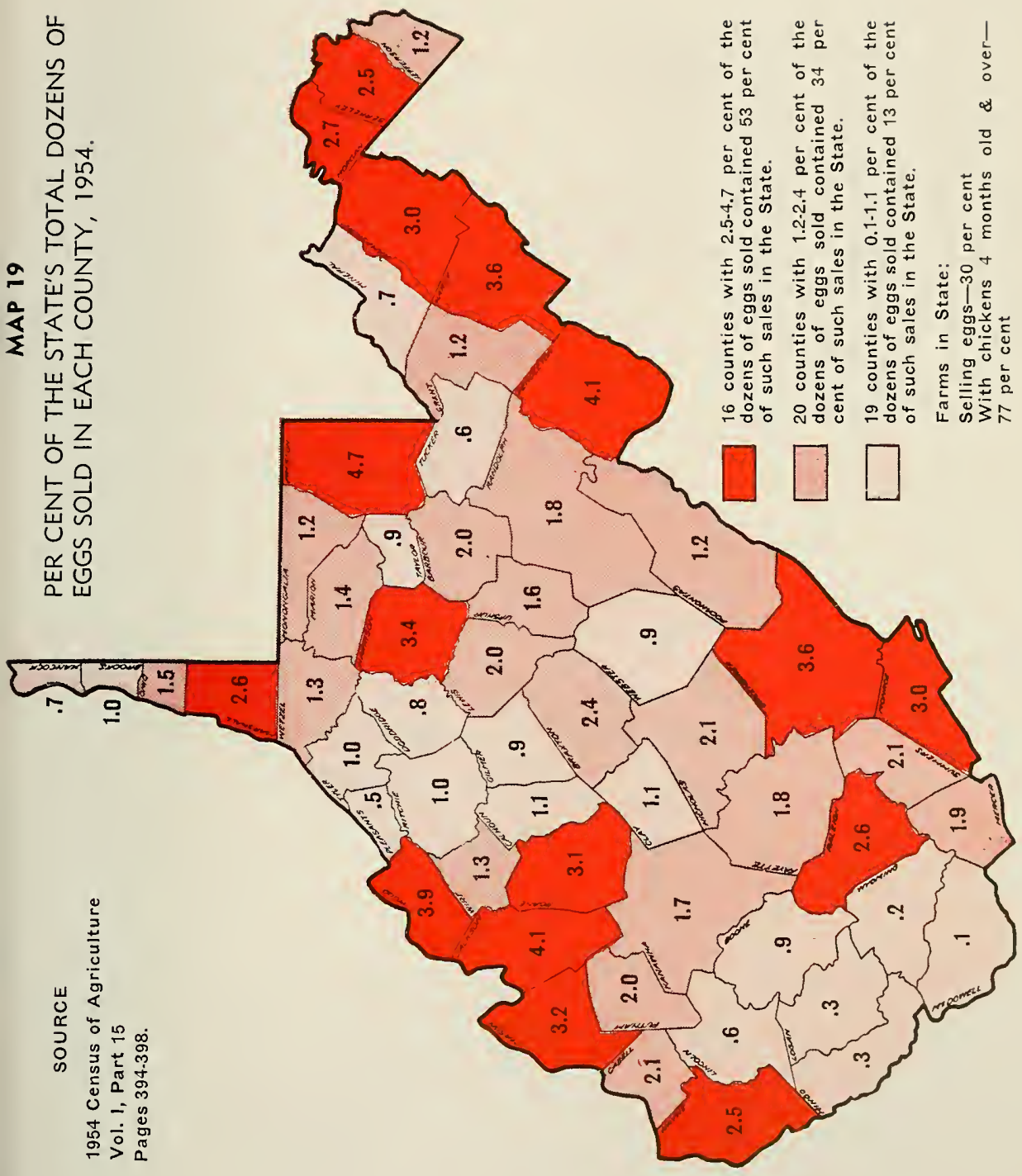




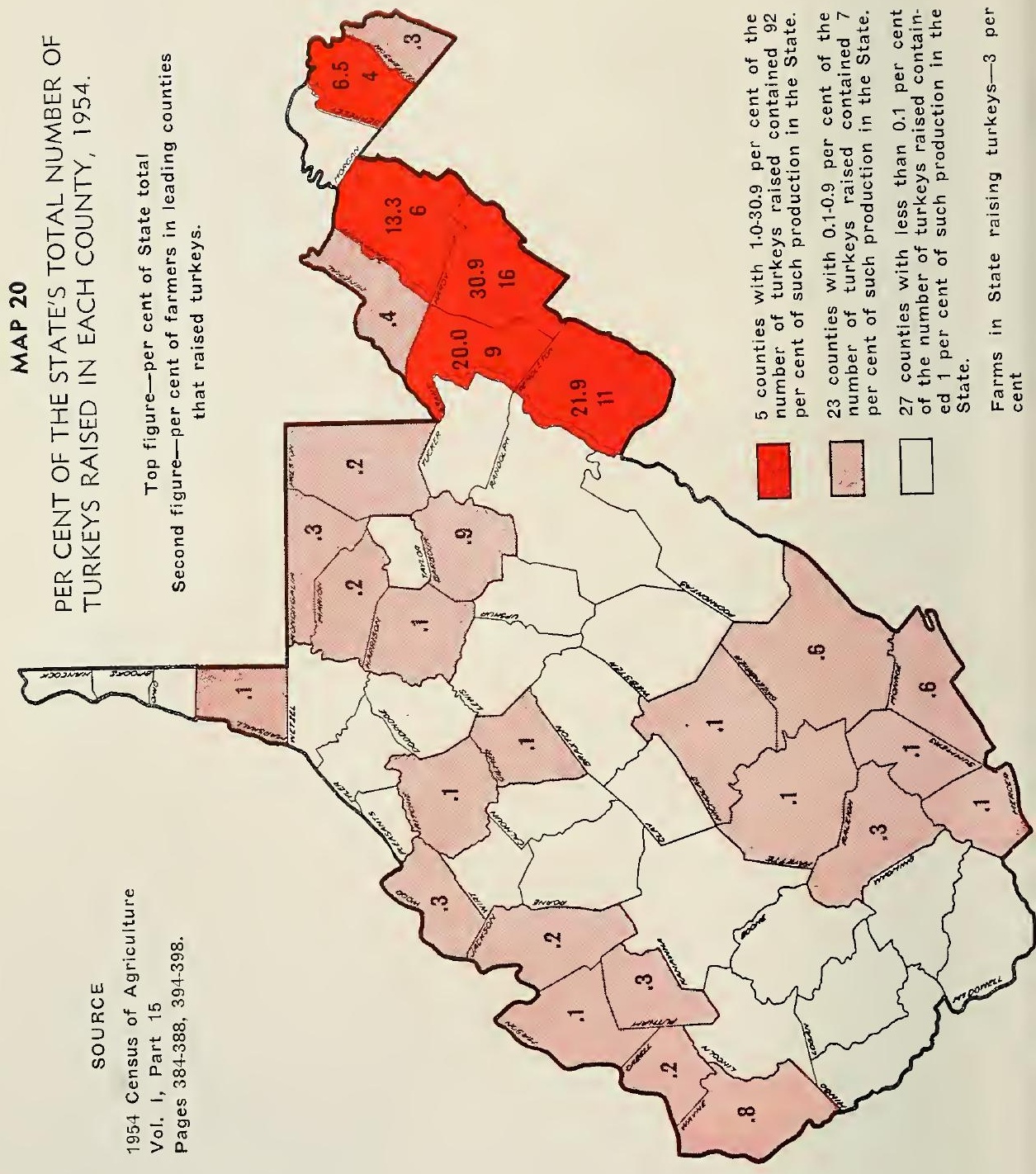




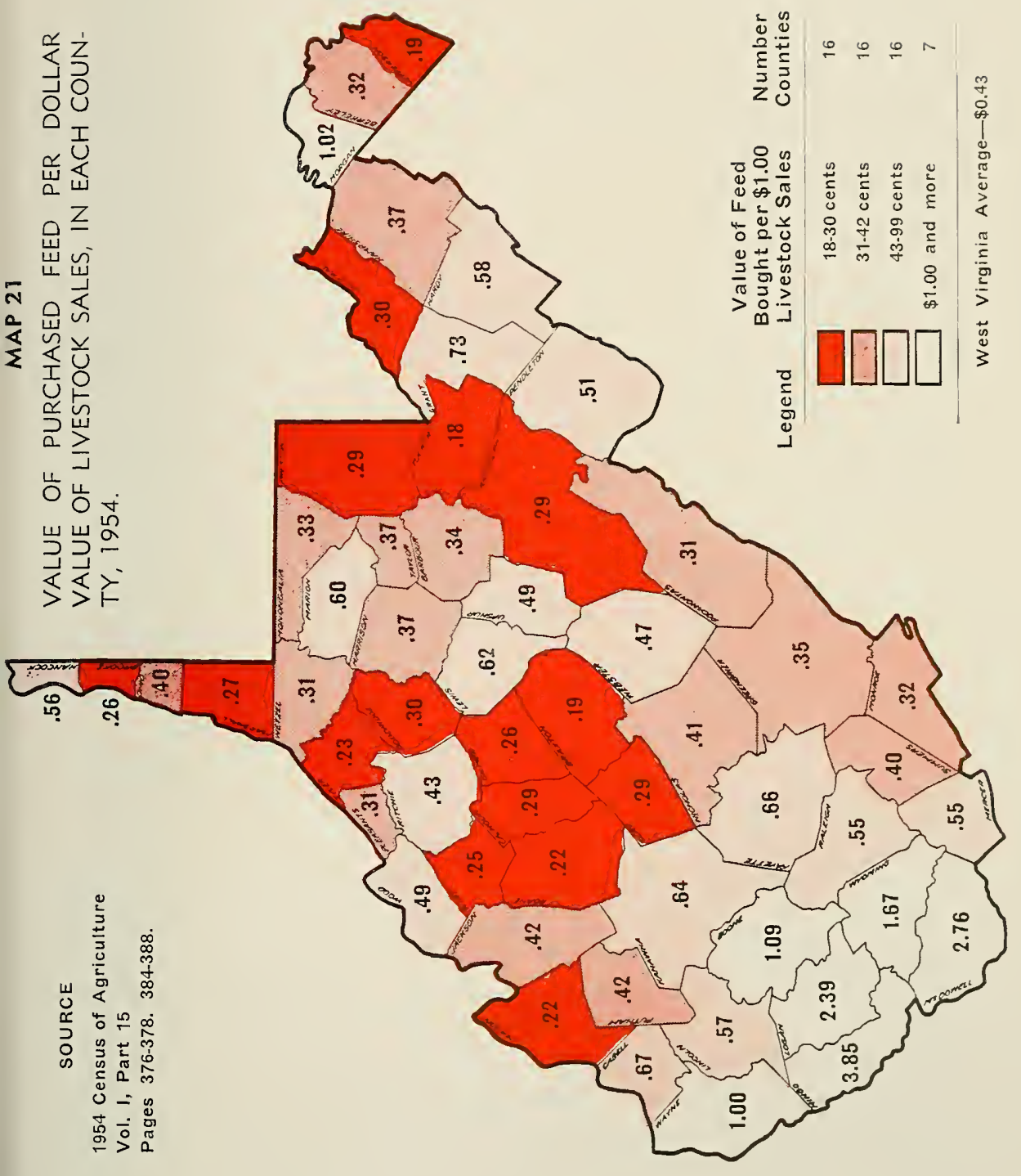


Thirteen per cent of the counties had feed purchases that exceeded the value of livestock sales. One of these counties was in the Eastern Panhandle, and the others were in the southwestern part of the State.

In some counties feed purchases were low relative to livestock sales. This indicates that home-grown feeds were utilized in producing market livestock.

In some counties feed purchases were high relative to livestock sales. In some of these, turkey and broiler production was relatively important and most of the feed was purchased. In some other counties a considerable proportion of the farms had low farm incomes. On these farms a large part of the livestock production was used for home consumption and their value did not become a part of farm sales.

Large expenditures for livestock and poultry feeds are concentrated in a relatively few counties. Three counties-Hardy, Grant, and Pendleton-account for 35 per cent of all feed expenditures in the State. These were leading poultry and livestock counties, and they were the leading counties in broilers and in turkeys. Hardy County was also second in hogs. Pendleton County ranked second in beef cows and in ewes and third in importance in sows and eggs sold.

One-half of the expenditures for feed occurred in eight counties. Besides Grant, Hardy, and Pendleton, the leading counties, in order of importance included Greenbrier, Hampshire, Lewis, Berkeley, and Jackson.

\section{Types of Farms}

In the 1954 Census, farms were classified by economic groupings. Major groupings include part-time, residential, and commercial farms. Only seven counties in the State had more commercial farms than partlime and residential farms.

Of the commercial farms each was classified on the basis of type of farm. In order to be classified in a particular type, sales or anticipated sales of a product or group of products had to represent 50 per cent or more of the total value of products sold. Six principal types were classified. These were poultry, dairy, other livestock, fruit, field crops other than fruit and vegetables, and general farms.

When all commercial farms in the State, without regard to their county location, were classified as to type, 40 per cent were livestock farms other than dairy and poultry. Another 22 per cent were dairy farms and 15 per cent were poultry farms. The field crop farms, other than vegetables and fruit farms, made up 11 per cent of the total. Fruit farms were 3 per cent, and 9 per cent were classified as general farms. 
Each county was also ranked on the basis of leading types of commercial farms. This ranking includect the three types haring the largest numbers of farms within each county. In a few instances a fourth ype of farm had similar numbers to that type listed as number three; however, these fourth types were not shown in the classification (Map 22).

When counties were classified on the basis of the leading type, 51 per cent were livestock other than dairy and poultry. This means that there was a larger number of commercial farms in these counties with 50 per cent or more of the income from beef, sheep, hogs, and goats than from any other type class. The income from livestock other than dairy and poultry was so important that 93 per cent of the counties had this classification in first, second, or third place.

Dairy counties were second in importance. Using the leading type of farm as the basis for classification, 24 per cent of the counties were classed as dairy counties. When all three of the top rankings are inclucle!. 69 per cent of the counties had a dairy type classification.

Only 5 per cent of the counties in the State were classified as poultry type on the basis of the first ranking. These counties were Grant, Hardy and Pendleton When all three of the top rankings were included, 56 per cent of the counties had a poultry type classification.

In 11 per cent of the counties, field crop type farms held the first ranking. However, only 18 per cent of all counties had field crop farms among the three leading types.

Only 4 per cent of the counties had more fruit type farms than other types. In total only 13 per cent of the counties had fruit farms among the three leading types. None of the counties had sufficient numbers of vegetable farms for this type to be listed among the three leading ones.

The general type of commercial farm led in only 2 per cent of the counties. However, this type was among the top three for 51 per cent of all counties.

\section{Ranking Agricultural Counties}

The 1954 Census of Agriculture ranked the 100 leading comnties in the Nation on the basis of selected items. None of the counties in West Virginia were among the 100 leading counties on the basis of value of all farm products sold in 1954. Seren counties in the State were among the leading ones in poultry or fruit (Table 9). All these counties are in the Eastern Panhandle area. 


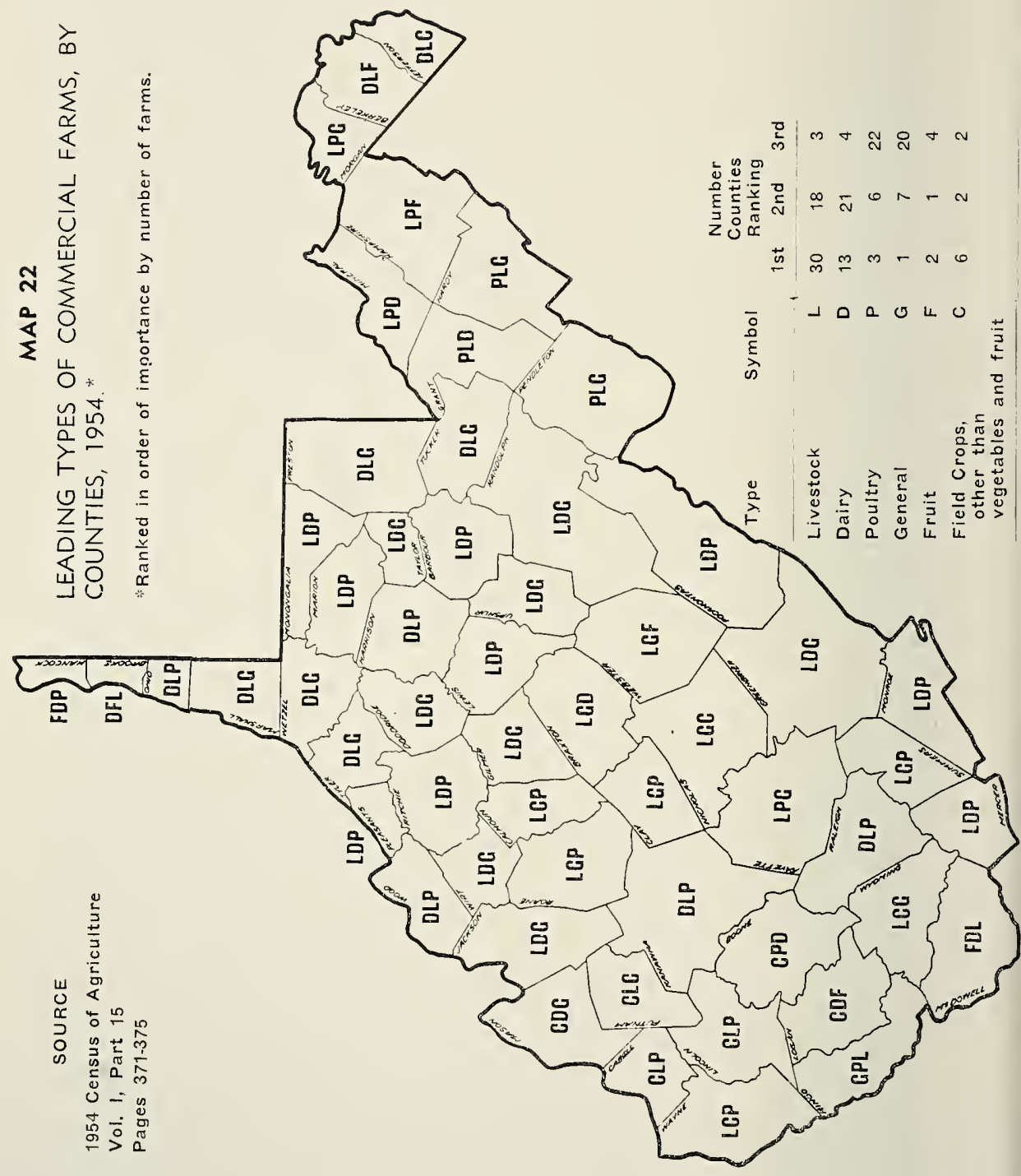


Table 9. West Virginia Counties Ranking Among the lo() Leading;

Counties in The United States, 1954.**

\begin{tabular}{|c|c|c|c|c|c|c|c|}
\hline \multirow{2}{*}{$\begin{array}{c}\text { Selected Items } \\
\text { For Ranking }\end{array}$} & \multicolumn{7}{|c|}{ RANKING BY COUNTIES } \\
\hline & HARDY & GRANT & $\begin{array}{c}\text { PENDLE- } \\
\text { TON }\end{array}$ & $\begin{array}{l}\text { HAMP- } \\
\text { SHIRE }\end{array}$ & $\begin{array}{l}\text { BERK- } \\
\text { ELEY }\end{array}$ & $\begin{array}{l}\text { JEFF- } \\
\text { ERSON }\end{array}$ & $\begin{array}{l}\text { MOR- } \\
\text { GAN }\end{array}$ \\
\hline 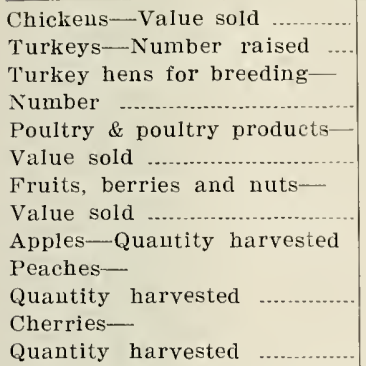 & $\begin{array}{l}29 \\
12 \\
15 \\
38\end{array}$ & $\begin{array}{l}46 \\
25\end{array}$ & $\begin{array}{l}33 \\
18\end{array}$ & $\begin{array}{l}25 \\
33\end{array}$ & $\begin{array}{r}63 \\
9 \\
22 \\
64\end{array}$ & $\begin{array}{l}66 \\
10 \\
\\
48\end{array}$ & 46 \\
\hline
\end{tabular}

*U. S. Bureau of Census, U. S. Census of Agriculture, 1954, Vol. 11I, Part 2, Ranking Agricultural Counties.

\section{Level - of - Living}

The economic position of farmers can be measured on the basis of level-of-living index. Such an inclex is available on a county basis for all counties in the Nation." The index was based on the relative position of farm families for electricity, telephones, automobiles, and average value of products sold or traded.

In 1954, the West Virginia average level-of-living inclex was below the national average, but above the low one-fifth in the Nation (Map 23). With the index adjusted so that West Virginia averaged 100, the national average was 132. An index of 95 and below was in the low onefifth in the Nation.

Within West Virginia the county level-of-living index ranged from 60 in Lincoln County to 158 in Hancock, Brooke, and Olio counties. Eleven per cent of the counties had inclexes in the top half of the Nation. These were the three most northern counties and the three most eastern counties. Another 31 per cent of the counties had level-of-living indexes above the State average, but below the national average. These were in the northern and eastern parts of the State. Nine per cent of the counties had indexes slightly below the State average, but they were not inclucled in the low one-fifth of the Nation. Nearly 50 per cent of the counties were in the low one-fifth in the Nation in level-of-living. These were in the central and southern parts of the State.

${ }^{9}$ Haygood, Margaret Jarman, et al., Farm-Operator Family Level-of-Living Indexe's for Counties of the United States, 1945, 1950, and 1954, USDA, AMS, Stat. Bul. 204 Mar. 1957. 
These economic situations among many West Virginia farmers are not good. They need to be improved. Improvements can be made. The more effort that is directed toward improvements, the more rapid will be the progress. Benefits from an improved agriculture are not limited to farmers. Others in the State will gain. Therefore, the problem is of concern not only to farmers but to others, particularly those in industry, education, and government. 


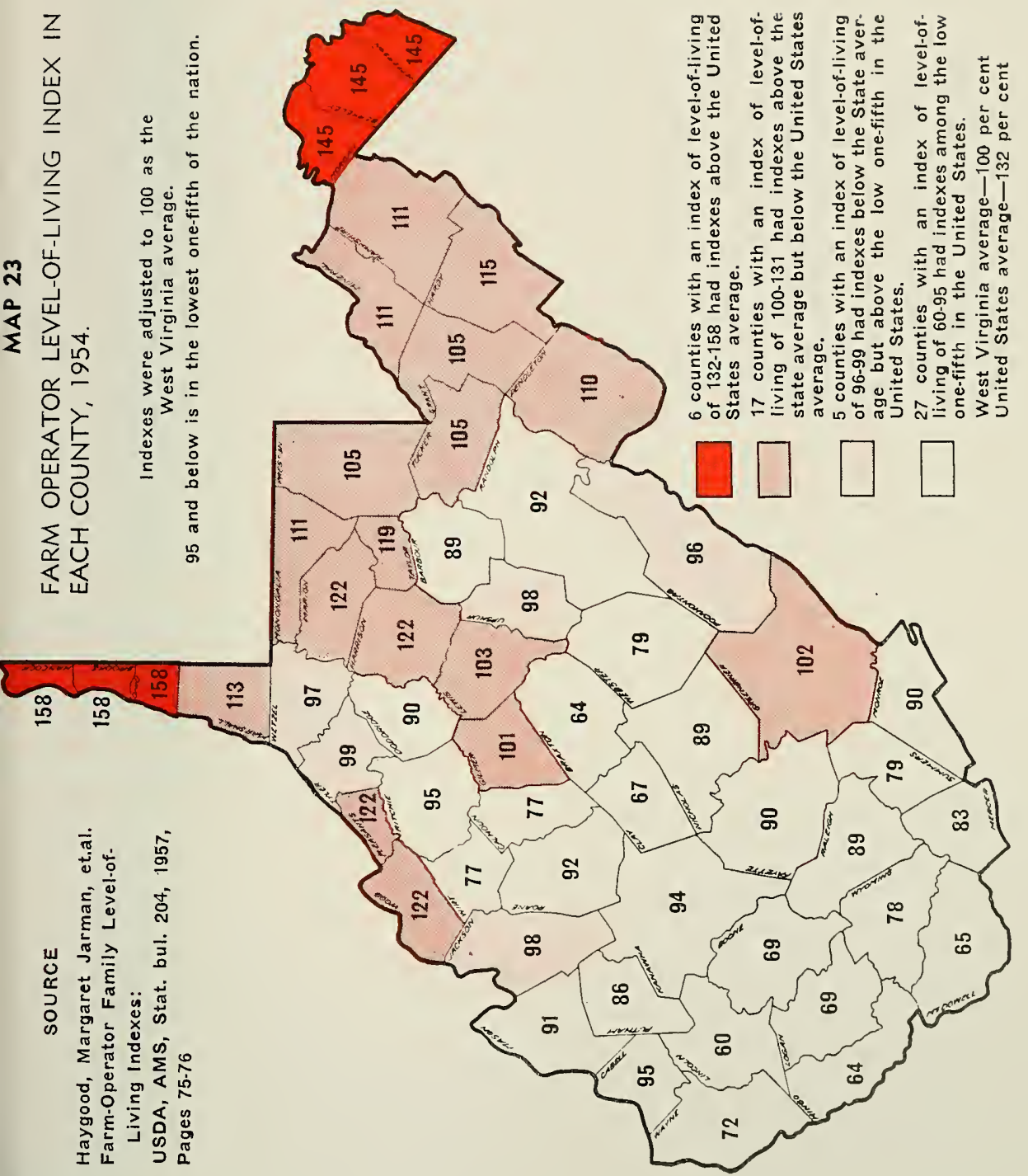




